\title{
Globalization, Diasporas, and Transnationalism: Jews in the Americas
}

\author{
Judit Bokser Liwerant ${ }^{1}$ (i)
}

Received: 21 October 2021 / Accepted: 6 November 2021 / Published online: 18 January 2022

(C) The Author(s), under exclusive licence to Springer Nature B.V. 2022

\begin{abstract}
This paper analyzes the structures and trends of the establishment, growth, and transformation of the Jewish presence in the Americas. After outlining several fundamental characteristics of the general continental societal environment and its internal differentiation, we critically discuss several theoretical approaches to a comparative assessment of the Jewish experience. Conceptual formulations include globalization, diaspora studies, and transnationalism, aiming to highlight their achievements and drawbacks. Selected sociohistorical aspects relevant to the development of Jewish immigration, settlement, and community formation are analyzed. This is followed by the exploration of more recent patterns, outlining emerging configurations and challenges. The article focuses on the differences and commonalities between the North (United States and Canada) and the diverse Latin American experiences. The conceptual referents imply rethinking the relationship between societies, communities, individuals, territories, and sociopolitical spaces along the changing contours of dispersion. Lessons from the past may help outline future paths.
\end{abstract}

Keywords Latin America · US · Canada · Immigration and emigration · Ethnoreligious minorities $\cdot$ Jewish community

\section{Introductory Remarks}

Recurrent conceptual concerns raise a primary question-how should the Americas be approached: as one, two, or many? As a reality, an idea, and a concept, the term "the Americas" is not univocal, since it covers very different regions. As a territorial, geopolitical, economic, social, multiethnic, and cultural entity, it can be outlined with a high level of generalization while also paying concrete attention to

Judit Bokser Liwerant

judit@liwerant.com

1 Faculty of Political and Social Sciences, Universidad Nacional Autónoma de México,

Mexico City, Mexico 
its components. The Americas are simultaneously a single ideal entity and many realities.

The Jewish experience in different subregions and countries of the Americas is equally pluralistic. Its internal diversity depends on the variety in contexts, time, and modalities with which it was inserted in the international scenario. Still, it is itself a carrier of an inner diversity it has inherited from its long historical and sociological trajectory in and outside the continent. Significant diversity prevails among and within commonalities_convergences and contradictions arising from the globally interconnected continent and the Jewish ethno-national/transnational diaspora.

Under such a conceptual and thematic umbrella, this article develops in a threefold way. First, it addresses the Americas, reviewing theoretical approaches to the continent and the frameworks for studying Jews as a collective that is territorially dispersed and maintains shared symbolic bonds locally and at a distance.

The second part focuses on Jewish communities in North and Latin America in the context of world Jewry. Migration flows were central in the relocation of Jewish life. Specific interactions between particular societal constraints and opportunities in a given country or region and the unique character of Jewish backgrounds and integration patterns are outlined.

The third part analyzes the current changing patterns of collective life and community, addressing old and new trends. The changes in the perimeters and scope of organized communities and the encounters and intersections they favored in the Americas stimulated convergences and divergences under the impact of globalization, transnationalism, and the changing profile of the diaspora.

Significant and inescapable difficulties consistently hinder the goal of integrating the geopolitical with the socio-communal and cultural dimensions of Jews in the Americas. Indeed, while the importance of national, regional, and transnational axes varies across time and space, their contours point to dynamics that exclude reductionist conceptions, emphasizing only one of them. The combination and juxtaposition of the broader regional/continental and global axis and the axis focused on the particular context of the Jewish ethno-religious group can be expressed in numerous ways. Contradictory situations run through the whole range of options, from, at one end, the complete autonomy of the Jewish experience with respect to the general societal sphere to, at the opposite end, total dependence on it; between the Jewish search for legitimacy, equality, and diversity and conformity with the non-Jewish majority; between the sociability of individual lives of Jewish citizens within national societies and gregariousness in their collective institutions; between a sociocultural identity of the Jews in total synchrony with the national ethos of each country and a specific identity and creativity whose symbolic and intellectual center is elsewhere, rooted in a nation/peoplehood/global Jewish collective (Bokser Liwerant et al. 2011).

This paper aims to offer an analytical and critical reflection upon profound links, convergences and divergences, tensions and encounters, and the vitality and richness of the meeting of a continent and its Jewish diaspora. The conceptual referents imply rethinking the relationship between societies, communities, individuals, territories, and sociopolitical spaces along the changing contours of dispersion. At stake are the modes of incorporation and dialogue of minority groups as owners of their 
particular history and identity within civil societies driven by their foundational principles and explicit agendas. It thus opens, together with Sergio DellaPergola's following article in this issue, the wide parameters that guided the project Jews in the Americas.

\section{The Americas: Identifying the Object}

The Americas' foundational experience emerged as an outcome of the expansive trajectory of European modernity, the configuration of the world system, and the globality of the Jewish trajectory fueled by successive waves of immigration. How did these different universes cross and intercept? How was the transnational character of Jewish migration to the Americas conceived? Was the diasporic extraterritoriality of Jewish immigration seen as convergent or conflictive with the particular founding ethos of the Americas?

The Americas may be thought of from a historical perspective, transitioning from their incorporation into the expanded World Order (or into the West) to a new insertion into contemporary globalization. Although there is no agreement among scholars regarding the Americas' origins or basic characteristics, a convergent approach identifies radical changes that have upset spatial, geographical, and/or territorial references (Giddens 2002; Allen et al. 2012; Coleman and Underhill 2012).

Over the last 500 years, increasingly dense and intense interactions brought about by capitalist labor markets, commodity production, and the political expansion of the nation-state, as well as large-scale migrations, wars of conquest, and the flow of goods and ideas, lie behind globality and globalization. While today the continent is impacted by the contradictory nature of the world configuration, facing differentially new horizons of opportunity and regional and sectoral backlashes, it cannot be forgotten that it was globally constituted and incorporated into the world configuration by an extension of the European experience (Wallerstein 1974, 2011; Eisenstadt 2000, 2002; Preyer 2013; Bokser Liwerant 2015b).

Sustained global dynamics developed through either central or peripheral connections to external centers as sources of its "encounter" or "discovery" genesis, which provided the parameters for the institutional creation and the conceptions of nation-building. These original centers were referents to be either followed or disputed. Different experiences and cultures subjected to global immersion and global awareness were embedded in the ways they built their incorporation into expanded world geography into globality (Roniger and Waisman 2002; Bokser Liwerant 2015b). According to Immanuel Wallerstein, the modern world-system was born in the long sixteenth century, when the Americas as a geo-social construct became its constitutive act. There could not have been a capitalist world economy without the Americas. The destruction of indigenous populations and the importation of the labor force from the peripheries of the world did not imply the reconstruction of economic and political institutions but rather their virtually ex nihilo construction. To fully function, the Americas resulted in a mosaic that reinforced extension and inequality among its fragments. Thus, it entailed structural relations between 
trans-scale poly-centers and poly-peripheries within the space it encompassed. Indeed, the transatlantic axis between Europe and the newly produced Americas was the first zone of the consolidation of the world system (Wallerstein 1974, 2011).

Shared and differing paths developed in the continent: coloniality in Ibero-America consisted not only of political subordination to the Crown(s) in the metropole, but above all, of European domination over the native populations. On the other hand, in the British-American zone, coloniality meant almost exclusively subordination to the British Crown; that is, the colonies constituted themselves initially as European societies outside of Europe (Quijano 1989). The conquest, colonization, and Christianization of America by the Iberians in the late fifteenth century occurred at the beginnings of the world market and capitalism. The arrival of the British to the northern parts of America more than a century later took place when this new historical process was already fully underway. The two Americas began the nineteenth century under unequal conditions and pursued quite distinct paths. The United States followed a pattern of development of the new and unusual Americanness or Americanity, with its inner disjuncture and contradictions-ethnicity, race-racism, the new world. It constituted itself as a nation at the same time as it was developing an imperial role as a hegemonic power. Latin America instead fragmented itself. There were bloody border wars and civil wars all over. Power was organized on a seigneurial-mercantile basis (Quijano 1989; Crespo et al. 2018). The national boundaries would not prevent the development of a sustained and intense transnationalist path of interaction among them (Roniger 2011).

Fernand Braudel devoted important chapters of his work $(1982,1986)$ to the contrast between the two Americas. Two civilizations: on the one hand, the ensemble of wonderful achievements, "future life," and the New World par excellence; on the other, the torn, dramatic ensemble, pitted against itself: the "second America" (Braudel 1986). According to him, the North was characterized by strength, activity, independence, and individual initiative; the South by inertia, servitude, the heavy hand of the colonial powers, and all the constraints inherent to the condition of "periphery." 
Indeed, distinct models related to institutional patterns, cultural premises, traditions, and historical experiences developed. Eisenstadt's concept of Multiple Modernities underlies profound tensions, contradictions, and paradoxes arising from the different phases of an emerging interconnected global world and the heterogeneity and contingency of different historical developments. There are two main axes around which two broad configurations crystallized in Europe would be projected in the region: those of hierarchy-equality and relatively pluralistic "ex parte" versus a homogeneous "ex toto" conception of the social order would be extended to the Americas (Eisenstadt 2000, 2002; Roniger and Waisman 2002; Bokser Liwerant 2015b, 2019; Ben-Rafael and Sternberg 2016). In the North American colonies, this was carried out by dispersed autonomous groups, many of them Protestant sects and various groups of semi-aristocracy gentry like settlers and merchants, with the Anglican Church and the British government playing only a secondary (although certainly not negligible) role (Eisenstadt 2002; Katz 2010). In the South, the conquerors' power had to come to terms with and, in fact, destroy and replace impressively developed local civilizations. Therefore, facing the modern West and searching after it entailed a confrontation with an alien culture imposed upon these local cultures from the outside. After the first wave of conquest by the conquistadores, changes were carried out under the centralized aegis of the Crown (or Crowns) and the Church, which monopolized access to the major resources of the colonies (land and labor) and in principle denied the settlers any significant degree of self-government beyond the municipal level (Domínguez Ortiz 1976).

In the North, the pre-conquest civilizations were much more decentralized, and their de facto destruction left significantly fewer traces in the body of the new colonial order. Hence, the new rulers only had to deploy a reflexive exercise in coming to terms with their own distinct place within the broader framework of European or Western civilization. This historical bifurcation of experiences ended up shaping in structural and ideational spheres the ways in which Jews were seen and conceived: their admittance, incorporation, social integration, and representation as legitimate dwellers of the public sphere. As displayed in Fig. 1, the multiple levels that framed these processes draw complex and differing scenarios. 


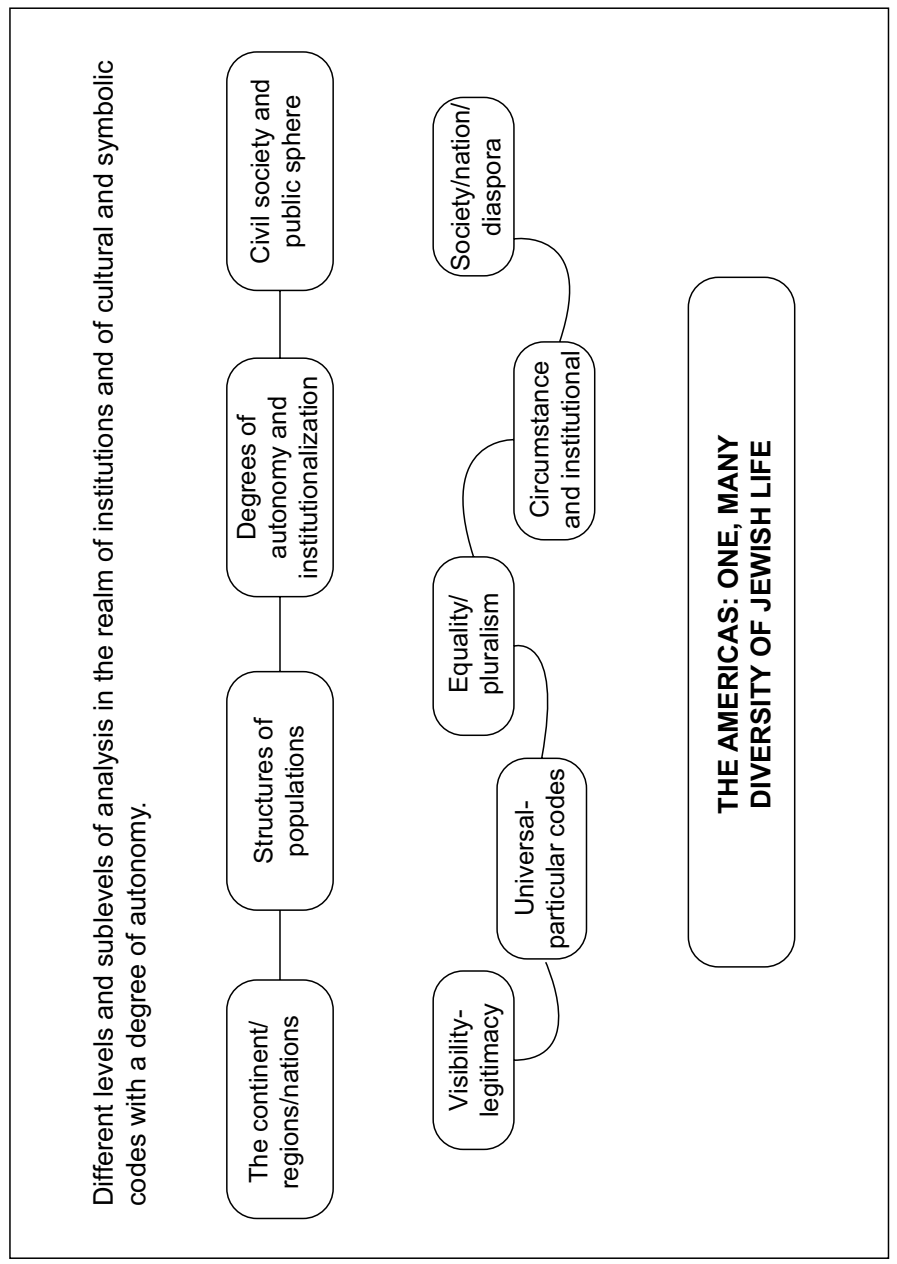

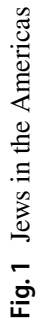




\section{Conceptual Approaches: A Promising Albeit Debated Triad}

The Americas represent an exemplary case in which historical paths and changing conditions interact. Globality as a foundational element and globalization processes shaped the changes in the Americas' social and communal structures, while the local and the global intertwined. Dynamic patterns of interaction developed historically between Jewish communities and their societal milieux, shaping Jews' changing status as citizens in nation-states, holders of a transnational condition. Both the continent as a whole and its Jewish presence were defined by human displacementssettlers, conquerors, various sorts of migrants-while modernity and modernization marked them differentially over time. Modernity's structures and layers generated mixed social formations straddling the past and present and imported, translated, and recreated lifestyles and customs from other places and cultures.

Jewish collective life has historically been displayed in multiple arenas-territorial, communal, religious, national, and cultural-and in different political-ecological settings; the Jewish world is shaped by the parameters of globalization, transnationalism, and diaspora. While by globality we mean the incorporation-foundation of the world system, globalization refers to the radical changes that upset spatial, temporal, geographical, and/or territorial references, without which it would be impossible to think of economic, political, social, and cultural relations in the contemporary world (Robertson 1992; Waters 1995; Scholte, 1998). Time and space cease to have the same influence on the way in which social relations and institutions are structured, owing to the conjunction of technical factors that shape the density and speed of cross-border connections, and involve the de-territorialization of economic, social, cultural, and political arrangements; they depend neither on distance nor on borders, and neither do they have the same influence on the final shaping of institutions and social relations (Giddens et al. 1994). Globalization processes are not uniform, as they take place in a differentiated manner, with territorial and sectoral inequalities. They are multifaceted, insofar as they bring together economic, social, political, and cultural aspects, as well as the interdependence and influences between these levels, and contradictory, because the processes can be intentional and reflexive, at the same time not intentional, and of international as well as regional, national, or local scope. Globalization implies the widening, intensifying, accelerating, and growing impact of worldwide interconnectedness (Held et al. 1999); it links people together across borders more than in the past and confronts them with cultural and ethnic differences (Appadurai 1996). It also confronts communities of dispersed people, the Jewish diaspora- a global diaspora, an ethnonational and transnational diaspora-with similar, convergent, and divergent paths, due to the increased circulation of individual and collective social agents and values.

Indeed, globalization processes accelerate migration, owing both to social inequalities and to the opening of opportunities (Urry 2000; Kellerman 2006, 2020). Migration and transmigration movements lead to diverse expressions of transnationalism. As a result of the latter's multidimensional nature, we underscore its contributions to the understanding of past trends, ongoing changes, and of yet uncertain developments (Appadurai 1996; Ben-Rafael et al. 2009). The concurrent relevance 
of transnationalism to the diverse historical times provides a conceptual tool that allows for a better assessment of the social morphology as expressed in the changing character of communal and social formations.

Contemporary social science research in transnationalism focuses mainly on recent migration groups (Glick Schiller et al. 1995; Portes et al. 1999; Khagram and Levitt 2008). Transnational studies examine mainly, if not exclusively, diasporic practices, projects, and attitudes of new diasporas (Moya 2011; Bokser Liwerant 2015a). However, by conceptualizing historical transnational patterns of shared values and norms, social belonging and collective identities, it is possible to recover cultural, religious, social, institutional, and economic linkages of a more permanent nature. Surpassing individual actors on the move, central common aspects of the Jewish experience may be recovered. There is indeed the challenge of analyzing the foundations of a scattered people committed to its continuity and bound through cohesion and solidarity.

Dispersion has been central to Jewish self-understanding for millennia. Modern Jewish historians took a global stance: from Heinrich Graetz in the nineteenth century to Simon Dubnow and Salo Baron in the twentieth, world histories became the parameter, emphasizing the longue durée and a transnational perspective. Their approach came out of the specificity of Jewish historical studies, where a disciplinary, ethno-national focus became dominant within a general, neo-positivist scientific program that analyzed national minorities in Eastern Europe. However, in the social sciences the study of diasporas arrived late. Before the 1960s, immigrant groups were generally expected to shed their ethnic identity and assimilate to local norms. During the 1970s, when assimilation theories based on the meaning of integration models were factually and conceptually questioned, "diaspora" was increasingly used to describe migrant groups maintaining their ethnic tradition and a strong feeling of collectiveness (Bruneau 1995; Shuval 2002, 2003; Anteby-Yemini and Berthomière 2005).

As its use became extended, the discussion of its applicability to different groups and the singularity of the Jewish diaspora as archetypal took over academic debates. The continued use of the concept of diaspora exclusively for the Jewish people was questioned or branded as a mistake. However, the extension of its historical experience to other groups often disregards the interwoven character of Jews' associational and organizational networks and the historical and symbolic layers of contact with the homeland (Sheffer 1986). Robin Cohen (2008) suggested that the archetypal Jewish diaspora could be a base for reflection even if it couldn't be a transposable model. William Safran considered that diaspora could be seen as a "metaphoric designation" and could apply to various populations: the rapid spread of the term "African diaspora" in the late decades of the twentieth century, expatriates, political refugees... Hence the concept of diasporas as expatriate minority communities that are dispersed from an original "center" to at least two "peripheral" places; that maintain a "memory," vision or myth about their original homeland; that "believe they are not-and perhaps cannot be-fully accepted by their host country"; that see their ancestral home as a place of eventual return when the time is right; and whose group consciousness 
and solidarity are "importantly defined" by this continuing relationship with the homeland (Safran 1991).

The structures and channels through which continuous relationships are maintained-diaspora building-remained a latent, underdeveloped topic of study. The literature highlighted the dispersion of its members, the orientation toward an ethnonational center-real or imaginary-considered a homeland, and the maintenance of the group's ethno-cultural borders in the host country (Cohen 2008; O'Haire 2008; Brenner 2008; Esman 2009). Sheffer's distinction between state and stateless diasporas and Cohen's cultural dimension defined diasporas as somewhere between "nation-states" and "traveling cultures." Long before, Tartakover (1958) had spoken of "portable states"-dwelling in a nation-state in a physical sense but traveling in an astral or spiritual sense that falls outside the space of the nation-state. Indeed, diaspora was also theorized by James Clifford (1994) as cultures of circulation, which, on par with de-emphasizing the paradigm of the ancestral home-center, rescued from the Jewish model a "virtual and intangible space" between the center and the periphery of dispersion. Diasporas are conceived as communities dispersed across space yet connected through an intangible connection to another time and place; he emphasized the "lateral axes of diaspora," the "decentered, partially overlapping networks of communication... that connect the several communities of a transnational people." Although highly fruitful for the interconnections of Jewish life in the Americas, it displayed some surprising reductionism. Following almost exclusively Boyarin's paradigm of diasporism - not only as a conceptual formulation, but as a meta-theoretical and political stance-it failed to acknowledge the singularity of the Jewish experience as an ethno-national diaspora with a Center-historical, spiritual, national. The strong links and the mutual influences became part of divaricate networks and multidirectional exchange, involving not only people, capital, and political resources but also ideas and cultural values (Levitt 2001; Bauböck and Faist 2010; Burla 2015; Asscher and Shiff 2019). Diasporas' presence in societies, the multicultural dimension they carry, the relations they create between original and new homelands and their dynamics as interconnected cross-national spaces are part of the transition of societies to a new era (Ben-Rafael 2013a, b). However, the historical weight of Jewish diaspora's structures that endure both local associations and channels of communication cannot be underestimated.

The necessary mediations between studies on transnationalism, globalization, diaspora and research into contemporary Jewry are still lacking. Despite the plethora of local descriptive studies, Jews are comparatively understudied in contemporary research, where they seem to have lost their historical resonance. Most importantly, there is a relative dearth of discourse about communal foundations in the available literature on national and transnational social relations (Glick Schiller et al. 1995; Portes et al. 1999; Pries 2008; Bokser Liwerant et al. 2010).

In contemporary Jewish studies in the Americas, the diasporic experience has been approached mainly from the perspective of historical migration and ethnic studies, frequently disregarding the analytical angle of Jewish diasporic formations, where systems of collective organization have accounted for interconnection and world circulation (Goldscheider and Zuckerman 1984). Thus, researchers relying solely on ethnicity cannot account for the necessary articulations of boundary 
maintenance and the mechanisms that counterbalance the loose nature of the collective. The limits and pitfalls of the ethno-communal paradigm in times of multiculturalism, postmodernity, and porous ethno-religious borders are analyzed, while national frontiers dilute the interconnection among the diaspora, the center, and the lateral axes. In the study of American Jewry, the notion of a stable ethnicity fixed by religion, language, and genealogy has been challenged by the difference outlook, emphasizing the contextualized and personal shaping of this identity category (Hollinger 1998; Lederhendler 2011; Magid 2013). In Latin America, migration studies have been the dominant approach. The conceptualization of a theoretical framework of diasporas and their current moment may be found in studies of postmodernism, oriented principally by the concept of boundary erosion. At the same time, the ethno-national Jewish diasporic experience has been analyzed from the sociocultural and political perspectives of Otherness (Bokser Liwerant, 2013).

We suggest that the dyad "being national-being transnational" provides the conceptual tool required to analyze local contexts, while recovering the commonalities and interconnections derived from transnational Jewish history. It critically questions the currents developed by historians and social scientists that focus on Jews as citizens of the nation-state, disregarding the singularity of a people whose traditions, identities, solidarity, commercial, social, and religious connections crossed borders, regions, and states (DellaPergola 2011; Avni et al. 2011; Bokser Liwerant 2013a; Kahn and Mendelson 2014). This interconnected binary contributes by addressing the current functional imperative of reproduction of local social domains through their interdependent relationship with globalization, implying that the global is localized and the local is generalized, reproduced by significant intercourse among societies and communities.

In the vast Americas, diaspora must be considered at an analytical level that accounts for its strong impact and differing consciousness across Jewish communities. Transnational studies that show an interest in the diasporic practices of new émigré ethnic communities tend to focus on the hybridization of identities and cultural fluidity and religious syncretism, rather than analyzing diasporic patterns derived from the maintenance of ethno-religious borders. They tend to refute diasporic practices that have observed the principle of boundary maintenance. We recognize that efforts to conceptually connect diasporas indeed contribute to outline their commonalities (Ben-Rafael 2016a). However, brought together with diaspora studies, they oscillate between boundary maintenance and boundary erosion (Brubaker 1994; Bokser Liwerant 2015a).

Boundary maintenance, as a systematic process of diaspora-building, should be analyzed through the lens of the vast associational and institutional foundations of organized collective life, which foster certain levels of mobilization and the organization of exchanges between its members. The individual and communal levels interact through dense and stable Jewish national and transnational organizational channels that enhance informal ethnic and family links and networks. At the collective level, however, associative resources re-elaborate and reorient organized Jewish life (Bourdieu 1986; Coleman 1988). The degree of formalization or institutionalization is characterized by a solid collective historical experience and memories that bring together temporal dimensions expressed by long-term trends, as expressed in 
Jewish life in the multiple Americas, notwithstanding its sharp differences in organizational patterns and collective awareness. The historical singularity of the different cases contributes to theory precisely in its communal building dimension, that allows scholars to approach and expand conceptual elaborations in transnational social fields as anchored spaces (Bokser Liwerant 2013a; Levitt and Glick Schiller 2004).

\section{Into the Region: Structures, Obstacles, Trends}

A crucial distinction between the basic civilizational premises of the United States and those of Europe and many of the Dominions, Upper Canada and Quebec included, has been the strong emphasis on the metaphysical equality of all members of the community, on egalitarian individualism, and on the almost total denial of the symbolic validity of hierarchy (De Tocqueville 2002). These conceptions and premises became components of a new collective identity and a new constitutional order. The transformation was such that it constituted the crux of the American Revolution and set it apart from other wars of independence (Restad 2014; Katz 2010). A vast variety of immigration flows contributed to the national character. In these contexts, conditions were favorable for the historical arrival and incorporation of the Jews: the belief in and value of immigration and of individualism and individual rights.

\section{The United States}

From the country's inception, although perhaps not yet fully, Jews enjoyed the status of what later came to be known as a post-emancipation Jewry, just as even in the colonial era, though not yet completely, the country was a post-emancipation country. Indeed, the nation was built on immigration, which meant Jews were welcomed into the plural design of the collective.

The principal elements defining modernity-i.e., liberal, secular, pluralistic politics; diversity in matters of culture and religion; and a competitive capitalist economic system with free, open markets-were salient factors (Wooldridge and Micklethwait 2005). Constitutional freedom and cultural pluralism made a tremendous difference to Jews (Eisen 1986); it led to the incorporation of the different groups into a collective higher order, while the right to self-fulfillment viewed normative support as part of the national ethos. Society promoted individual gratification, which in fact led to tolerating communal diversity (Sarna 1997, 2004). A singular constellation defined United States Jewry, whose presence was closely related to the process of nation-building and endowed its visibility in the public sphere. Consequently, the collective organization of Jews favored a decentralized congregational model based on denominational pluralism. Until fairly recently, Judaism as a religion was assumed to be the primary axis of distinction, yet the singular dynamics between religion and ethnicity frequently led to the acceptance of the former as a 
way of expressing the latter. Individualized Jewish religiosity developed around the synagogue-congregation and was gradually embedded in a public Jewish "civil religion" (Bellah 1967) understood either as a set of civic tenets or probably also as a Jewish ethno-national solidarity that, in the view of some observers, attained a quasi-sacralized status (Woocher 1986; Fischer 2010; Fischer and Last Stone 2012).

The United States would be described, especially since the mid-twentieth century, as a country with "three religions": Protestantism, Catholicism, and Judaism (Herberg 1983). Inner religious differentiation, the presence of Reform Judaism, the establishment of the institutions that formed and provided renewed religious personnel, and rabbinical seminaries all cultivated a rich and inner diverse Jewish life.

Society fostered an individualized pattern of incorporation that challenged collective frameworks. Though preceded by the Sephardic presence-individual Sephardic Jewish settlers were recorded in the 1620s preceding the 23 Jews from the Sephardic community in the Netherlands who arrived from Recife, Brazil, in 1654 in what was to become New York-looking at the paradigmatic and exceptional Jewish New York and its foundational organizational pattern, a differentiated subnational/ethnic population was reflected in the patterns of uptown and downtown Jewish immigrants, the former from Germany, the latter from Eastern Europe. The place and role of German Jews on the continent were closely related to their early arrival and the surrounding milieu, both of which reinforced being seen as the epitome of modernity, socioeconomic mobility and assimilation. The term, therefore, didn't exclusively refer to the territory or the political geographical entity but rather to German culture-immigrants from German-speaking countries were the bearers of the symbology of progressive, acculturated and assimilated Jews (Brinkmann 2014). Jewish organizational life outside the synagogue was based largely on local, regional, and national membership associations and social welfare federations, interwoven with the Jews' other associational habits and social connections in a pluralistic and individualized manner (Phillips 2005; Waxman 1983).

While intense organizations were developed-mainly philanthropic and charitable ones by German and Central European Jews and mutual-aid societies by immigrants from Eastern Europe-the kehillah as a centralized structure developed overseas did not crystallize. (There was a single initiative of this kind; it began in 1915 and only lasted until 1922.) What did succeed-first in Boston, and later in New York-were Federations of Philanthropic Organizations. The Old Home was seen as a past from which to depart. Eastern European Jews did develop a solid Jewish culture brought from and connected to overseas in an intense diasporic dynamic; writers, artists, poets, and a Yiddish press gained strength and simultaneously provided an organizational axis. The strong symbol of the later circulation of culture was epitomized by the YIVO-The Institute for Jewish Research, dedicated to the preservation and study of the East European Jewish culture and history. Located in Vilna from 1925 throught 1940, due to World War II it was relocated to New York. Circa 1928, a branch was established in Buenos Aires, as Fundacion IWO. A global diaspora and its changing geographies and histories!

Immersed in the concrete/ideational tension of allegedly cutting ties with the countries and cultures of origin, the Jewish US community has often been 
represented as exceptional by its history of success. Concomitantly, its selfunderstanding and history-writing have been focused within the borders of the country (Kahn and Mendelsohn 2014). However, comparative research has shed light on various spheres of strong connection to the regions and towns of origin of US Jews, be they commercial, financial, social, or cultural (Kobrin 2012). Certainly, Old World attachments were reconfigured, and texts and contexts redefined through mutable and multiple ways fundamental to the new life.

Narrative and reality, national projects and achievements were mutually shaped. Americanness called for Americanization as the path to follow. Simultaneously, Americanization meant a new way of being Jewish, learning a new code derived and defined by the new society (Sarna 2004; Diner 2004; Lederhendler 2019). US Jewry progressively experienced the growing legitimacy of its ethnic assertiveness that reinforced the cultural referents of its collective identity. Americanization as an ideal and a value - with its strong call for a new identity-also explains that immigrants sought in education the clue for adaptation and integration rather than for continuity. Education in private Jewish communal institutions had, until recent decades, been the exception rather than the rule, as most Jewish families had sent their children to public schools.

As far as the civil incorporation of Jews and its relative success are concerned, much depended on the timeline of their presence. Upon arrival, the ideal was no hierarchy in a nation under God; in practice, there were very structured hierarchies by race, ethnicity, region, and country of origin, marked by the succession of large-scale waves of immigration, each of which found its place within the hierarchy. This, of course, affected the place of Jews, who in most cases entered into the lowest ranks. At the same time, the US allowed for a robust upward mobility.

The positive depictions of Jewish immigrants produced by scholars such as Park, Thomas, Wirth, and Stonequist were not representative of general American attitudes toward Jews in the 1910s and 1920s. As historian Tony Michels (2010) has pointed out, a considerable body of scholarship "shows that American antisemitism increased in intensity and popularity from the mid-nineteenth century into the mid-twentieth century; it extended beyond the social realm into political and governmental spheres; and it turned violent more frequently than we usually recognize" (p. 212). Only after the Second World War did circumstances improve (Alexander 2006; Dash Moore 2009). During the postwar era, the Federation system served as the primary fundraising and redistributive body of the American Jewish community and progressively the locus of American Jewish power (Kelner 2013; Friedman and Kornfeld 2018). This communal system was part of the civil religion that provided extended symbols, rituals, and practices.

Nowhere did the tension between the Center and the diaspora become so early and strongly expressed in the Americas as in the US. Zionism, as an idea and as a movement, had to deal with the challenge to its diagnosis of exile and a diaspora consciousness. Jewish-American intellectuals rejected the equation of the United States with galut and Israel with Zion. While it also provided a collective reference axis, it carried a conflictive dynamic as an identification referent and a principle of legitimization (Eisen 1986, 2014). The impact of the destruction of European Jewry 
on the general and Jewish political action and agency can be seen in the redefinition of the world Zionist agenda and of US Zionism in its support for a Jewish state. Indeed, the vision of a Jewish state and the possibility of transferring millions of Jews there were the outlines of the program of the Biltmore Conference of May 1942 (Penkower 1985; Bokser Liwerant 1991; Sasson 2015). With the establishment of the state, the core opposition developed into a tacit agreement and collaboration. Gradually, it became a functional referent and a central theme for building the Jewish presence in the public sphere. It influenced the conceptualization of the American civil religion of survivalism (Woocher 1986) with secular peoplehood as its main religion; secularization, influenced by Protestantism, equated Jewishness with Americanization (Goldscheider 2003; Cohen 2003), transformationalism, a vibrant communal life (Goldscheider and Zuckerman 1984; Silberman 1985).

United States Jewry developed as a center fostering transnational ties and facing overseas needs; it acquired world relevance precisely through the establishment of structural channels: associations and institutions that advanced joint efforts in addressing worldwide Jewish needs.

\section{A Different North: Canada}

While conceived as multicultural from its inception, the founding trajectory of Canadian Jewry was binational, bicultural, and bi-religious. Cultural diversity was implied from the country's origin with British and French settlers, as well as the ever-present need for increasing immigration into their territory. This diversity was, however, based on Anglo-Canadian Protestant values, which were prevalent at the time, and this was reflected as strict migratory regulation with distinctly racial criteria. It wasn't until after World War II that a transition was enacted from a restrictive immigration policy that favored white European immigrants toward a universalistic policy in accordance with Canada's international position as the spearhead of human rights advocacy.

Both the organizational pattern and the arenas to build continuity reflect the position of Jews in society. Although it would seem well situated in terms of integration into Canadian society (Brym 2018; Weinfeld 2018), at the turn of the twentieth century, as their numbers were increasing, Jews were in many ways acknowledging their outsider status in the country and their ethnic or national independence, their existence as "a third solitude" (Greenstein 1989). The community endured legally sanctioned discrimination in accommodation, employment, education, and immigrant admission (Troper and Weinfeld 1988). In the words of Elazar and Cohen (1985), Canadian Jewry from the turn of the twentieth century through World War II behaved as largely segregated Jewish communities had for centuries; in many ways, it was an exemplary multicultural community in a country that was imperfectly multicultural.

From the 1960s onward, the Jewish profile adjusted and benefited from the legitimacy of its transnational dimension. Its institutional density combined and overlapped ethnic, religious, and cultural roots, national Jewish allegiances, and a sustained openness to renewed waves of immigration. Therefore, the inner diversified 
associational map strengthened the different levels of group cohesiveness; no external claim to erase primordial identities competed with this dynamic. The balanced development and stability of Canadian socioeconomic configuration led the country's Jews to pursue integration into society through entrepreneurial capitalism, advocacy, and nondiscriminatory government policies. Jews followed the strategy of compartmentalizing private and public spheres of the collective, combined with selective cultural synthesis. Jews turned inward and developed a vibrant communal life of their own (Brown 2007). Ethnic cohesion, a national identity less demanding in its plurality as a main referent, and a consequent communal institutional density defined the main parameters of Canadian Jewry.

Education-as a central sphere for social-cultural-institutional underpinningwas a space to build both continuity and difference. Before World War I and beyond, Canadian schools were either Protestant or Catholic (in Quebec, French Catholic). At the beginning of the twentieth century, Jews in Quebec were legally deemed Protestants for school purposes. Otherwise, they would have had no right to public schooling at all. In Ontario, Protestant schools became "public" after World War I; the publicly funded Catholic schools remain separate, but tax-supported, to this day. The schooling of children and young adults in comprehensive Jewish educational institutions took priority over other needs of the community. In Toronto neighborhoods with a Jewish majority, Jews could and did run for public school director in the early decades of the twentieth century. More than half of the children receiving Jewish education attend Jewish day schools, a substantially greater percentage than in the United States and in most of the community of Latin America, except Mexico (Pomson and Deitcher 2009; Miller et al. 2011; Tickton Schuster 2019). The Jewish educational system indeed provided the structural substratum for cultural singularity amidst other instances of cultural uniqueness. The traditional and Zionist content of education must be highlighted. Zionism found its roots based on both ethnicity and nationality.

The diversity and richness of sub-ethnicity found expression in the literary work of Yiddish writers - a terrain where it could recover an Old World culture and build a secular creative space. The roots and paths of circulation of cultural creation, seeking to build ethnicity on cultural grounds, crossed the Americas from Canada and the US to Latin America and back, in search of a Jewish culture not reducible to religion. While the latter would not be absent, neither was it regarded as normative (Levinson 2009).

Canada's strong Jewish life can be neither explained nor understood if Israel as a concrete, ideological, and mythical center is not sufficiently analyzed. For Canada, as for Latin America-with differing codes of nationalism-the Zionist idea and Israel have been determinant. Various associational and structural spaces were expressed and shaped by spiritual-national-cultural representations of the Center, paralleling the autonomy and vitality of the lateral axes of the diasporic configuration. Lastly, the Canadian dialectic of particularism and universalism can be paradigmatically seen in the shared struggle for Jewish recognition and human rights (Abella 2006). If circulation and diaspora influences are analyzed, its tendency to incorporate the struggle for human rights into its agenda developed in a relatively early phase. 


\section{Latin America: The Region's Diversity and Comparative Remarks}

The Jewish presence in the more than 20 Latin American countries draws a global diaspora defined by the diversity of its singular contexts. Differing from the nationbuilding of Americanness and Americanization as a goal in the US and from the multicultural ethnic saga in Canada, Latin America's distinctive search for national identity rejected diversity as a risk to its recurrent aspiration toward uniformity, understood as synonymous with national integration and therefore interpreted as part of its quest for modernity.

The difficulty in seeing Jews as collective actors, as legitimate inhabitants of the public sphere, was built and narrated differently. In the Southern Cone and in Euro-American countries, where mass migration modified the population profile, it took shape in a public sphere that was allegedly neutral vis-à-vis private differences, consistently with the idea of secular and liberal thought of a national identity constructed on the supposedly integrating foundations that homogeneity provides. The national subject was not understood in its diversity; the Latin American liberal narrative turned its back to the latter. In Indo-America, diversity remained a referent and bastion for the mestizos - whose indigenous ancestors interbred with the Catholic Spaniards-who became the essential national subject. The way Jews perceived and internalized this goal became part of the interplay between self-adscription and their social representation (Bokser Liwerant 2008, 2009).

In the Americas, societies offered different structural and legal frames and models of social interaction to ethnic minorities, influencing the integration and continuity of Jewish life. The ideational conception of the nation and the search for the collective were expressed in the foundational constitutional law of the countries, and thus settled the normative profile of the nation. It is important to assess under which general principles-as stated in the national constitutions of the different countries of the Americas-Jews could or could not be allowed to become an integral part of national society. In this regard, North and Latin America adopted entirely different approaches, whose relevance, however, was more symbolic than practical in terms of the effective societal integration of Jews and of their ability to have access to socioeconomic mobility and political participation.

In Argentina, the preamble to the Constitution mentions union, guaranteeing justice, securing domestic peace, providing for the common defense, promoting the general welfare, and securing the blessings of liberty to citizens, to posterity, and to all men of the world who wish to dwell on Argentine soil: "Invoking the protection of God, source of all reason and justice: do ordain, decree, and establish this Constitution for the Argentine Nation." Immediately it decreed that "the Federal Government supports the Roman Catholic Apostolic religion" (adopts it as the state religion). Massive immigration altered the goal of one uniform society; civil society had its own margins of tolerance to diversity, but the ideal representation of the Argentine nation-hence the expectation that Jews would integrate-assimilate to form part of the nation-was deeply rooted.

The Mexican Constitution proclaimed that the Mexican Nation is unique and indivisible. The Nation has a multicultural composition originally based on its indigenous peoples, "who retain their own social, economic, cultural and political 
institutions, or part of them promoting the awareness of their indigenous identity should be a fundamental criterion in determining to whom the provisions on indigenous peoples apply." Since the restrictive concept of mestizaje excluded Jews, their enclave character, as stated, excluded them as legitimate components of the national we.

As seen in our previous analysis, these two cases are distant from the Canadian and US constitutions. The former, facing both immigration and multiculturalism (or rather, binationalism) declared that Canada is founded upon the principles that recognize the supremacy of God and the rule of law, establishing for its plural minorities the freedom of religion as among the fundamental liberties.

As for the US, it approached immigration through the aspiration to unity, to "the need for oneness," to become "one People" as conditioned by its past ("to dissolve the Political Bands which have connected them with another, and to assume among the Powers of the Earth, the separate and equal Station to which the Laws of Nature and of Nature's God entitle them, a decent Respect to the Opinions of Mankind requires that they should declare the causes which impel them to the Separation." Immigration policies were another matter. In the twentieth century the quotas of the 1920s were clearly — although not explicitly_crafted to contain Jewish (and Italian) immigration. Canada followed suit (Abella and Troper 1982).

In Latin America, Jewish Otherness was embedded in the conception of the nation and in the policies concerning immigration and exile policy. Otherness was socially represented as foreignness amid debates that resulted in restrictive policies toward Jewish immigration and Jewish refugees and became a prominent sphere in which different hostile and rejectionist expressions were articulated. Their impact on the social representation of the Jew as the Other framed the arrival of Jewish immigration during the 1920-1940s.

Despite the transnational nature of immigration, the diasporic extraterritoriality of immigrant Jews was conflictive for Latin American countries, even for the founding liberalism of the national states that stimulated European migration. The regional institutions of the great ethno-national collectivities of Spanish, Italian, French, and German immigrants, notwithstanding their transnational imprint in the Rio de la Plata or Mexico, were not perceived as diasporas but as legitimate colonies of their motherland protected by the consuls and embassies. The transnational modality of these collectivities was perceived differently-and was different-from the case of the diasporic transnationalism of the Jewish immigrants. It certainly needs to be seen in comparison with the enclave modality of the integration of colonies of foreigners that did not require the "mestization" of white immigrants as happened with the model of the white European-Creole melting pot. The robust hypothesis concerning the Southern Cone is that Italian or Spanish transnationalism was not only legitimized in those transplanted immigration countries but was paradoxically used to legitimize their xenophobic nationalism against other minorities, inside and outside. Furthermore, the Jewish minority was questioned for having managed to organize communally as an ethno-national diaspora-colony, but an extraterritorial one (Senkman 2005; Bokser Liwerant et al. 2010).

The Jewish presence was built in the framework of strong interconnected communal boundaries. Latin American Jewry shaped its communal life along strong 
transnational solidarity connections and with a dependent or peripheral character. Jews from Eastern Europe succeeded in establishing transnational relations between the original centers of Jewish life and the new periphery that powerfully influenced its construction as a new, though connected, ethno-transnational diaspora. They gave rise to differing models of Jewish kehillot in the region as replicas of original experiences overseas, not seen or interpreted as a referent to be overcome.

A common matrix nourished the Jewish identity of its members: a feeling of ethno-cultural and transnational belonging. Despite associational fragmentation and its ideological, cultural, and socio-occupational heterogeneity, an ethnic diasporic matrix was shared by Jews ideologically identified with a variety of political orientations: Bundists, communists, or Zionists. Its objective was to raise an organic community that would offer services of religious worship, social and medical welfare, burial in a Jewish cemetery, and, fundamentally, formal Jewish education. The kehillah framework transcended the borders of local ethnic association in order to encompass both the will for integration in the country and, simultaneously, the transnational bonds among the entire Jewish people both scattered throughout the diaspora and concentrated in Israel. The Asociación Mutual Israelita Argentina (AMIA) became paradigmatic of collective Jewish life.

As in Argentina, the transnational relations that the Jewish community of Mexico forged significantly marked the construction of a new ethno-transnational diaspora that reaffirmed the paths of the old kehillah model. Thus, the diasporic matrix with its changing centers and collateral axes regenerated itself in its traditional models and practices. Continuity seemed to be the overall choice, and integration mediated by communal life was the strategy.

Contrary to what happened in the United States, the collective overshadowed the individual. Differing from the traditionalist-religious imprint of the northern communities, founded by secularists but seeking to answer communal and religious needs, communities were forged in the mold of modern European diaspora nationalism, emphasizing their inner ideological struggles, and organizing as political parties and social and cultural movements. The communal domain, while prompting continuity, became the basic framework for the permanent debates between world visions, convictions, strategies, and instrumental needs.

World Jewish developments gradually turned the Zionist idea and the State of Israel into central axes around which communal life developed and identity was built (Bokser Liwerant 2016c). Partly convergent with Canadian and US Jewry, and partly singular in its meaning and intensity, Israel brought to the forefront both the feeling and the objective reality of a transnational shared mission and commitment to an ideological, political, and cultural-spiritual center. It also represented a new chapter in solidarity efforts as well as ambiguities surrounding the true meaning of this evolving relationship between an ideological, political, and public center and Latin American Jewish communities. It expressed the inherent tension between the idea of a national project for renewing Jewish national life in a Jewish homeland and that of acting as a spur to foster Jewish life in the circumstances of the diaspora. Being Zionist in Latin America provided Jews with the possibility of having a homelandmadre patria too, either just as other groups of immigrants to the country had or as a substitute for the previous ones that rejected them. It can be defined as a diasporic 
condition and consciousness that reinforced an ideal one-center (Jerusalem) model with a dependent periphery. Latin America was alternatively seen as undefined and not clearly part of the West, or as part of a peripheral region; a shared perception of a temporary sui generis diaspora called to play a central role in the changing Jewish dispersion. Zionist sectors invigorated the center with both the "national home" and "refuge" qualities that simultaneously nourished and reinforced their own diaspora profile (Avni 1976; Bokser Liwerant 1991, 2016b).

In comparatively accentuated collective patterns, while Eastern European Jews, as hegemonic community builders, established the old/new communal structures, the Sephardic geo-cultural world developed communities of its own based on different countries or even different cities of origin, such as Damascus and Aleppo. This reflected the character of a complex Jewish ethnic group textured by different subgroups, communal links, and family networks. The maintenance of Sephardic trade networks, the circulation of knowledge, marriages contracted or dissolved transnationally, and the other networks of communication, relation, and interaction explored herein enabled the perpetuation of a modern Sephardic diaspora (Mays 2020). Sub-ethnicity provided vital inner interactions.

Similar to the case of Canada, education reflected and reinforced political and organizational diversity and a highly developed structural base that became the main domain to transmit, create, and project the cultural profile of Jewish communities; to construct differences between the communities and their host societies as well as inside the communities themselves. It acted as a central field for displaying Jewish collective life while negotiating the challenges of incorporation and integration. The role Israel played in its development gradually expanded, as the center that aimed to set itself as a focus to legitimately influence Jewish life outside its borders.

As in the rest of the Jewish world, the June 1967 Six-Day War may be seen as a watershed in terms of solidarity, cohesion, and mutual recognition in world Jewry (Lederhendler 2000). The responses it elicited illustrate the way in which a moment in history can become a "foundational event" where different dimensions converge: reality, symbolism, and the imaginary. Discourse and social action came together and stretched the boundaries that define the scope and meaning of us. The threat to the state was seen as a threat to the entire Jewish people-the people of Israel were defined as one undivided entity. Paradoxically, this turning point was progressively and radically reversed by an extreme expression of religious revival and desecularization. While the "miraculous" experience of the Six-Day War enhanced the links with Israel as the state of the Jewish people, it also reinforced the connection of the Jewish people with the land of Israel-a link recovered and channeled by the Orthodox world (Danzger 1989). Religious Zionism and the settlers were also nourished by this experience that led to strengthening biblical-mythical beliefs, connections, and symbols (Aran 1991; Dieckhoff 2003; Don-Yehiya 2014; Sagi and Schwartz 2018). Over time, this trend grew and reached in the early twenty-first century its utmost expression, in which religious allegiances, ideological worldviews, and instrumental considerations interact in interwoven and complex ways (DellaPergola 2020a).

Israeli internal discourse shifted its focus from the diaspora to new critical topics: the Occupied Territories and the Palestine question, but also religion-state relations. 
This political shift not only removed the inherent subject of Israel-Diaspora links from the forefront of the Israeli agenda, but it created inherent tensions because of the different political outlooks and institutional interests at both ends of the dyad.

Further transformations concern the concrete and potential cleavages over patterns of private/public developments and expressions of collective identity that cross both Israel and the diaspora communities in light of the diversified nature of the dimensions, actors, and institutions that interact and divergent political stands. Whereas communal political behavior related to transnational links and support for Israel and the capacity to influence decision-making intensified due to globalization processes, the latter generated new constraints derived from regionalization and the inner differentiation and geopolitical positions of the countries. In this respect, it reflects the complex interplay between a wider public sphere, the prevalence of traditional mechanisms for negotiation, the internationalization of the PalestinianIsraeli conflict, and the presence of divisions within the Jewish communities.

Surpassing a binary understanding of the diaspora-center relationship, coexistent and even competing cultural, religious, and political referents favor its conceptualization as a pluri-centered or even de-centered matrix that carries intense dynamics of convergences and divergences (Alroey 2008; Asscher and Shiff 2019).

\section{The Triad Today: Selected Snapshots}

Over recent decades, strong transformative trends crosscut the continent. The Americas lay the groundwork for observing the growing scope and intensity of globalization and transnationalism and their impact on the Jewish Diaspora's changing profile.

Transnational links became reinforced. Although the country/state of residence continues to be the frame of reference for everyday life, experiences are no longer exhausted in that space. Both the territory and the symbolic horizons of the nation have lost vigor through the multiplication and diffusion of cognitive and normative maps. Introjected globalizing trends in the national spheres have been combined with similar processes at the community level, generating competition between normative guidelines and interpretative schemes and making a single collective frame of reference challenging if not irrelevant. Thus, in the South as in the North, the idea of cultural diversity has distanced itself from assimilationist pretensions.

Jewish culture, as does culture in general, far from being compact and homogeneous, acts as a conductive thread for new scenarios of transnational fluxes of all kinds-immigration, transmigration, tourism; information technology (IT) and electronically transmitted images; postmodern ideas that call into question central educational institutions. The demarcating function of culture has been diluted, causing transfigurations of the traditional "behavioral genders" that kept the social world "in its place" (Yudice 2006).

Changes occur in broader foci that encompass emerging civic commonalities and particular transnational links. The Americas are experiencing differentiated transformations in the public sphere, in the criteria of membership, in the spaces and 
dynamics of identity-building, and in their political expressions. Sociocultural/ political parameters and limits to diversity are subject to changes, namely potential xenophobic and antisemitic expressions. Political pluralism, the acknowledgment of difference, and the emphasis on heterogeneity act as a substratum that stimulates and reinforces diversity.

In Latin America, through local differences, citizen participation has broadened, seeking to promote democratic integration, including minorities. Although the project of a civic community and the strengthening of civil society were cemented after the political transitions to democracy, the latter were characterized more by variability in the degrees of achievement than by their full implementation. The region's changing reality reflects both the increasingly expansive force of democracy and its recessions, regressions, and reconfigurations. Latin America has incorporated global cycles of political opportunities and social conflicts in contradictory ways, as evidenced in democratization and de-democratization processes, centralization of power, civic citizenship and ethnic allegiances, and the simultaneity, as well, of individualization of rights and collective affirmation. Multiculturalism and new claims for recognition of primordial identities seek inclusion based on essentialism, which previously dominated at the national level.

Canada, after the 1970s and 1980s, following the intense mobilization of ethnic minorities, proclaimed a multiculturalist policy; although it did not lack criticism (Guo and Wong 2015; Bannerji 2020) or inner ethno-national tensions, it followed a path of stability. A variety of elements enrich multiculturalism. Like other minorities, Jews continue to find expressions of their collective life while maintaining their internal ethnic cohesion.

In contrast, in the United States, the very idea of the nation was built upon history, both ideological and material, with a solid racial division that was deeply ingrained in the social structure of the country. Access to the public space (and even the territory) was hierarchized on a racial basis. Nonetheless, one of the ideas that prevailed was that of assimilation, the melting pot, and at least nominally equal opportunity. Changes began slowly in the 1960s, when the Civil Rights movement gained impetus and the Civil Rights Act was famously passed in 1964, and they developed in different directions. The sustained increase in the recognition of diversity also faced discriminatory nationalist reactions.

Outlined in terms of general trends, the impact of the context may be discerned in the interactions with Jewish community transformations, oscillating between boundary maintenance and boundary erosion. Frontiers bear witness to an epoch defined by underlying complexity. Important sectors have abandoned communal belonging while others have seen a flourishing and resurgence of collective Jewish life. Communal institutional foundations face new equations between being and belonging, religiosity and ethnicity, peoplehood and social stratification, changing hegemonies in the leadership and sources of power and consequent disputes. But scarcity of resources—real or perceived—underlies all of these dualities.

The perimeters of Jewish life have been (and are still being) modified. The limits and traditional functions of the organized Jewish communities evolve both in the rate of conventional affiliation and in the new spaces that emerged or were strengthened as a response to the increasingly integrated profile of Jews in society. In light 
of changing necessities, a significant turn in the financing of collective life has also taken place. Perhaps a paradigmatic example was the transition to new forms of privatized resources. Partially as an outcome and as a vigorous internalization of the dominant neoliberal patterns in society, US Jewry saw the growth of powerful private funds competing with, and even displacing, the Federations (Kelner 2013; Friedman and Korenfeld 2018). The behavior of private funds and banks supporting Jewish institutions shows differing patterns of responsibility. The common denominator of many institutions was the transformation of their past profiles to become similar to nongovernmental organizations, through innovative policies of social support. Both ex ante and ex post, these policies developed as internal fragmentations that reflect the socioeconomic and occupational stratification of the communities.

Simultaneously, the communal dimension is also perceived as just one of the possibilities of the existence of the social subject, whose self-construction takes many forms: as an individual, as a member of civil society, or as a participant in temporary frameworks that create contingent associative identities (Cohen and Eisen 2000). The transition from communal models based on a shared past to associative models based on changing shared interests gained impetus, defined by multiple belonging and increased integration, making it necessary for Jews to redefine their organizational axes. The private sphere is growing as a space for experiencing Judaism. While this is significantly marked in the US, it seems to bring the Latin American and the North American experiences closer, in the sense of re-dimensioning the individual realm for the construction of Jewish life. Are collective spheres seen as a guarantee of continuity? And how and where is continuity defined? (Kurtzer and Sufrin 2020) The individual-community binary constitutes, indeed, a clue to the alternate referents of structural cohesion and identity-building, even though the two elements differ in dominance. While in Latin America and Canada the community was the grounds for building Jewish life, in the US it emerged as an entity whose centrality was recognized as an alternative resource to religious practices and a means for enhancing Jewish identity precisely when its loosening was enunciated (Cohen 1988).

The collective associational dimension is correlated with differing indexes of ethnic cohesiveness such as community affiliation or Jewish schooling. While in the US the main indicators are closer to the Brazilian and Argentine communities at medium intensity, Mexico stands closer to Canada at higher intensity. Institutional orders, national cultures, and socioeconomic structures are projected in it. While the affiliation rate in Canada (70\%) and Mexico (85\%) is similar, Argentina, Brazil, and the US run between 45 and 50\%. Enrollment in day schools accounts for Mexican exceptionality (93\%) among the similar rates in Canada, Argentina, and Brazil (45\%), while the US oscillates around 25\% (DellaPergola 2011; Bokser Liwerant et al. 2015; Brym et al. 2018; Besser 2020).

The structural and functional changes highlighted here take place amidst the porosity of borders which paved the way for the emergence of religion, closely related to the weakening of the culture of its traditional boundaries, and its reconnection to new spatial and temporal configurations. Religion enhanced its role as a resource to address other social problems and as a means to a public ethical discourse (Voyé 2000). In parallel to reinstating the normative validity of the public 
sphere (Casanova 1994), the responses of orthodoxy and fundamentalism have become stronger, defending the enclave nature of the collective condition and taking positions as ethical referents in a context of credibility crisis. For its part, and defined by its historical trajectory as a circulation culture, the Jewish religious world in the Americas intensified and widened. The Conservative Movement expanded from the US to the South as a shift away from the original religious models of the immigrant generation. Its Northern congregational character was redefined, and the synagogue was relocated as a community space, which meant new options for building a Jewish identity committed to local society. In the South, specifically in Argentina, it allowed for an interesting de-secularization with no rejection of Zionism, while encouraging a concern for human rights—even preceding or paralleling the agenda of Canadian Jewry. The establishment of the Latin American Rabbinical Seminary in Buenos Aires and its role in training Conservative rabbis, a pattern that reversed the previous absence of religious officials, reinforced the community's structural foundations. The flux of rabbis from the South to the rest of the continent, particularly to the United States, pioneered a pattern of new transnationalism- the movement of religious personnel as actors and agents of social change (Bokser Liwerant 2013b).

Subsequently, the Haredi presence expanded both in the North and in the South, in consonance with Israel. The Chabad Lubavitch movement and the opening of its centers across the continent exemplify how changing socioeconomic and cultural conditions were catalysts to the development of social support networks and the reaffirmation of identity borders, addressing the need to reconstruct social tissue. The movement spread an alternative paradigm anchored in belonging and discipline, proposing an ideal moral code and expressing the quest for expectations unfulfilled by the prevailing organized communal life. It further developed following migration movements (Limonic 2019).

The modified interplay between historical ethno-national patterns and religious and transnational flows also found expression in new channels and social actors. While the Israeli religious scene has singular traits associated with its national milieu, including the pervasive phenomenon of vicarious religious belonging without necessarily believing and delegated functions (Bokser Liwerant 2002; Davie 2007; Fischer 2010), parallel manifestations of autonomous expression of the religious experience emerge both in Israel and in the diaspora. Religious transnational networks across communities and Israel are erasing the traditional spaces and mechanisms of interaction defined by borders between the voluntary collectives and the sovereign state. Religious frameworks provide the networks through which communities build agreements. Mexico City, New York, Buenos Aires, Paris, and Jerusalem are all nodes and fluent borderless spaces that define religious and ethnic interactions. Religious revitalization is not just a regional phenomenon: it can be characterized as articulating local and regional communities with a transnational community of believers/practicing Jews under the hegemonic centers located in the US or Israel.

These changes pose several questions, among which the matter of the institutions and their officials' financing is neither marginal nor tangential. Who is paying for them? Who has gradually approached this sort of spiritual framework and why? 
How and why have phenomena of a magical nature and an oracular character regarding the direction of personal affairs expanded? We could venture a parallelism of paradoxical combinations of the privatization of religious orientations and sensitivities, the weakening of the institutional dimension of religion, and the re-emergence of religious components, orientations, and sensibilities. In turn, movements (and orthodoxies) have been transformed and transposed at the center of national and transnational activities (DellaPergola 2008; Bokser Liwerant 2008b). Thus, America's communities and Israel need to be seen in their inner and cross-border diversification. Undoubtedly, this connection between competing centers and lateral axes redefined the diaspora matrix.

The complexity of these trends becomes apparent in the parallel growth of cultural or secular patterns of identification and organizational belonging, thereby moving and fixing old/new definition and membership criteria. More than the synagogue, other fields and activities of identity-building have received new impetus. It is worth underscoring literature, theater, and film as privileged terrains where the new trends, expectations, and claims regarding the social imaginary are expressed. They became a meaningful part of social discourse, expressing meanings, narratives, images, and tropes of the changing historical experiences and new social constellations. Paradigmatic of it has been contemporary cultural production, where gender and the search for identity converge. It could even be defined as an extraordinary literary boom of being Jewish in the Americas - the individual problematic of collective belonging, the existential queries derived from the tension between the efforts of privatizing the historical dimension of identity, and the diachronic density of the subjectivity of Jews.

\section{South to North and Beyond}

Decades after the founding migrations to the Americas, renewed migration waves became central factors of social change for those who move and those who stay, for the communities in the countries of origin and for the new communities built abroad. The new interconnections are marked by the relocations in the lateral axes and the center(s) of Jewish life. Partly convergent with other ethnic diasporas and partly in their uniqueness, Jews are engaged today in a renewed geography of dispersion and concentration. A complex logic of interdependence between the new homes, the previous ones, and the historical ideational ones widens Jewish social experiences.

The Americas entered the twenty-first century with differing experiences, as part of a single world order in which the US still occupied a top place and Latin America a subordinate one. A more systematic articulation of the Americas emerged under the hegemony of the US, including Canada in a secondary role. Among the visible and significant manifestations of this development is the growing migratory flux from South to North, especially to the US. Latin American migration expresses the interconnection between globalization, diasporas, and transnationalism.

The emigration of Jews from Latin America to the United States is part of this larger, global phenomenon of unexpected scope: the international migrant stock has grown from 153 million in 1990 to 271 million in 2019 (United Nations-Department of Economic and Social Affairs 2019). In 2017, about 37 million Latin Americans 
lived outside their country of birth (compared to 35 million in 2010) (Pew Research Center 2019). Latin American Jews are part of the cohort of qualified migrants who increasingly move to OECD [Organisation for Economic Co-operation and Development] countries. Over the past few decades, close to 250,000 Jews from Latin American countries have undertaken cross-border migrations. Given the global estimates, it appears that close to 36 or $37 \%$ now live outside the region (DellaPergola 2020c).

Indeed, Latin America has become an exit region for broad social sectors. Societal crises and individual choices converge, determining timing and characteristics (Bokser Liwerant et al. 2010; Bokser Liwerant 2015c). As a result, in complex and interrelated ways, Latin American Jews have transitioned from communities of immigrants to communities of citizens and, simultaneously, of emigrants.

Contemporary international and regional migration, integration, and distinctive mobility account for the new scaling of spaces where collective Jewish life is relocated. Diversified waves of migration both reflect and create diverse territorial, cultural, sub-ethnic, and social paths (Sassen 1998; Castles 2000; United Nations Development Programme 2019, 2020).

The collective dimension implicit in this relocation and the new profile of communities in the making might be analyzed in light of the "migration crises" of the Latin American region, i.e. the worldwide emigration, dispersal, and regrouping of migrant communities generated by macro-level forces of a political and economic nature (Van Hear 1998). Successive migration crises affecting Latin Americans took place during the second half of the twentieth century. The first phase began with the Cuban Revolution in 1959 and continued intermittently, chiefly during the 1970s in Chile under Salvador Allende's socialist government and later under the authoritarian regime of Augusto Pinochet (1973-1990). Emigration also ensued during the era of military dictatorships in Brazil (1964-1985), Argentina (1976-1983), and Uruguay (1973-1985). The later phases (mid-1980s and 1990s) were caused by the combined effects of neoliberal economic policies and globalization affecting Argentina on two occasions, as well as Uruguay. Colombian Jews emigrated during that period due to a generalized atmosphere of violence within the country. More recently (mainly since 2000), the Jews of Venezuela have emigrated under the impact of the populist regime initiated by Hugo Chávez. Emigration from Mexico was relatively more stable, with peaks in the mid-1990s, in 2010, and at the end of the 2010s. The ways in which streams of migration change shed light on moments of transition. Sharp declines in the Jewish population have occurred since the mid1980s in Central American countries. However, in the case of Guatemala, more than half of its Jewish population decided to stay in their homeland. Neighboring Costa Rica increased its Jewish population by two thirds since 1967 while Panama became a relocation country for Jews fleeing from other Central American countries. Argentina has experienced some of the most acute political and economic crises, yet still hosts the largest Jewish population in the continent (Bokser Liwerant et al. 2010).

Contemporary American Jewry and the encounters that take place within it may be better understood when considering the challenges of integrating newly arrived groups: multiple dynamics of joining/receiving, of being/belonging into the extant reality of the veterans dominated by prevailing self-images and discourses (See Fig. 2). 


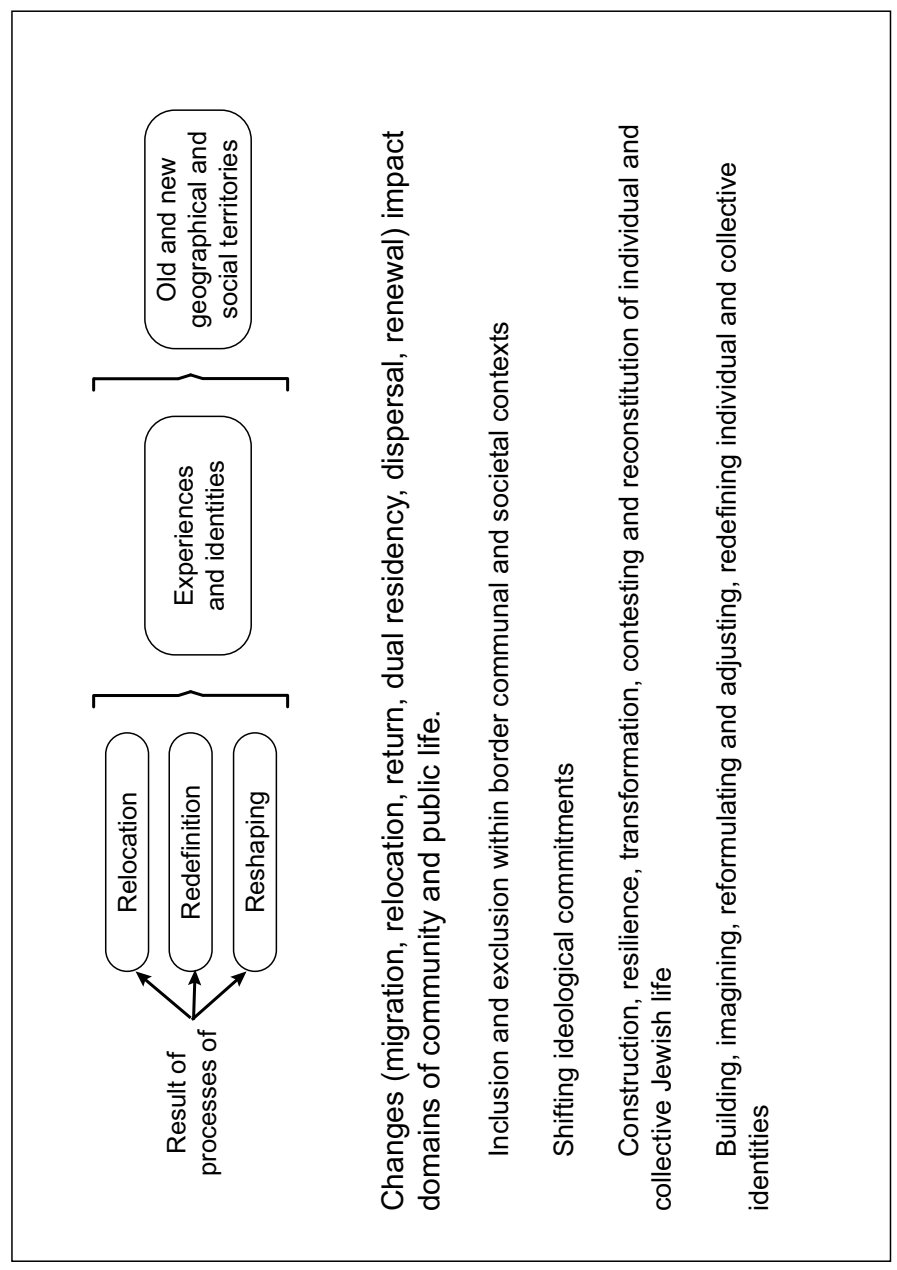

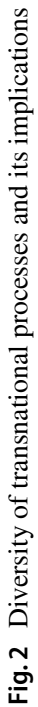


Jews migrating across and out of Latin America simultaneously disperse and regroup. We are witnessing the recovery of the historic trajectory of ethnic and ethno-national patterns of migration and the pluralization of migrant populations. This conjunction between two interrelated aspects implies both an enhancement of Jewish globalization and the reinforcement of particular, local aspects of the Jewish experience. This requires a dual terminology: diaspora and transnationalism are related concepts that are applicable to the contemporary itinerary of Jewish dispersion in the "new global ethnic landscape," as Appadurai (1996) calls it. Mobility and relocation set the stage for the potential reconstitution of an enlarged, redefined ethno-religious and national/transnational collective.

Latin American Jews do not simply replicate social relations transferred from country of origin to destination society (Levitt 2001; Nonini 2002); rather, their subjective and socially expressed experiences are quite diverse. Boundary maintenance between origin groups may be complicated (undercut, refracted, blurred) by interactions and by the plausibility of multiple identities: a sense of being Latin American may thus coexist with a sense of being Jewish, Colombian, Mexican or Venezuelan, Latino or Hispanic, or perhaps a more general awareness of "being immigrant Jews on their way to becoming Americans."

Jews in the United States live in "stacked social spaces" characterized by high levels of foreign-born residents. These spaces, which share sociodemographic and ethnic-racial contexts, extend over the noncontiguous geographic spaces in American society, hence questioning what Ludger Pries (2008) calls the past predominance of "mutual embeddedness of social practices, symbols and artifacts in unilocal geographic containers" and the "complete conjunction of the social and the spatial." We can thus conceive of these communities as the territorialization of a differential net of diasporic spaces (Brah 2011) which comprise a large number of multiple realities, intertwined with its local, national, and regional circumstances, and still maintain the communication thread through the experience of diaspora in and of itself.

The Latin American Jewish case is an apt choice in that regard, since Latin American Jewish immigrants in the United States have invested strongly in establishing the institutional support structures for a collective identity. The relatively high degree of formalization and institutionalization is supra-local, as it was when establishing Jewish life in the South; that is, group organizations and institutions embrace far more than local communal needs and attachments. Jewish communal life is thus characterized by strong collective historical bonds that transcend national borders and find expression in diasporic and transnational practices. The case at hand can mediate between discourses of national (nation-state and political) migration studies, on the one hand, and individual or family-based migration and transmigration studies, on the other (Portes et al. 1999; Beck 2007; Amelina et al. 2012).

Several paradigmatic fields and patterns can be identified in locations with a strong collective Latin American Jewish presence, where agency and structure interact in a differentiated scenario of places and actors. Their relocation takes place in existing and reconfigured spaces of American Jewry. It occurs largely because unique and shared Jewish dimensions allow for sociocultural embeddedness amidst 
inner diversity. Paradigmatic of this trend is the array of educational choices. Social integration and encounters between the different and the similar often entail new cultural trade-offs. Social boundaries are maintained, though bifurcation and overlapping occur - as expressed through a revised articulation of social and cultural markers, as in the case of family unity, ideational connectedness with the State of Israel, memorialization of the Shoah, and sensitivity to antisemitism. These values-once perceived as stemming from the Latin American Jewish experiencemay now come to be regarded by some as more universally Jewish. Others, to be true, would assertively oppose such an importation of paramount Jewish diasporic values into American Jewish discourse. The institutional map of the educational system accounts for both cultural and socioeconomic factors.

The sub-ethnic axis shapes the strong connectedness among migrants independently of their country of origin and across global cities. Simultaneously, religious differentiation acts as a hard divide in providing affiliation and spaces that also crosscut place of origin. The way national origin overlaps with religious origin is deserving of attention. The inner religious divisions in Judaism and a Latino panethnic identity develop together with both a Jewish comprehensive ethnic belonging and a fragmentary religious one. Countries of origin, cities of destination, and sociodemographic and ethnic-racial contexts and time frames are variables that influence and shape a diversified world.

Redefining and reconnecting their attachments, migrants are involved in processes of diaspora-making and diaspora-unmaking. Various scenarios emerge as they experience de-socialization from their country and community of origin and re-socialization in the country and community of destination (Van Hear 1998). Variability, complexity, and heterogeneity seem to be the rule. Thus, Greater Miami mirrors the cycles of migration crises in the region, starting with the first Jewish Cuban collective migratory/exiled wave and successive crises in the region. The expansion of a transnational community took place in new frontier areas such as Caribbean Florida or the American Southwest where complex dynamics developed, grounded in patterns that are particular to each national group but are generalized also within a large population. A shared sense of living in a community with other Latin Americans, the existence of communal organized spaces that represent group continuity, and the presence of a critical mass enhance new social regrouping by allowing migrants to establish and bolster formal and informal networks based on their common origins.

In San Diego, an ethno-national enclave with a transnational character developed among Mexican Jews, leading to what may be termed a secondary diaspora. The migrant experience in the North-East-Midwest triangle and its counterpart in Texas represent individual-professional cases, rather than collective migration patterns. Age, gender, and household composition-selectively younger and nuclear-provide interesting doors of entry and mapping routes into associational connections. It is thus possible to further question and analyze a scenario of de-diasporization that could lead to either individual integration or new prevailing criteria and axes of regrouping.

The US opened a wide spectrum of the legacy Latin Americans bring with them and accounts for the increasing transnationalism of the Jewish world. American 
Jewish life has been transformed by general social and communal patterns with distinct implications for continued collective communal life: transitions from individualization to collective affirmation, and their subsequent reversal; from congregational to communal models, albeit simultaneously witnessing a growing role for synagogues; from secularization to rising expressions of new forms of religiosity, even as secularism appears to be gaining ground; from privatization to communal revival. These trends are not linear but rather reflect changing moments, fluctuations, and interacting paths and are both cause and effect of a transnational overall interconnection.

Such dynamics may be approached as encounters between peripheral alterities and central alterities. Latin American Jews in particular may be seen as bearers of peripheral identities vis-à-vis the Anglo-Protestant core culture. On their side, American Jews face a certain degree of dissonance between their subjective sense of being "insiders" and those aspects of the Jewish experience that reflect their difference as "outsiders" (Biale et al. 1998; Rohrbacher 2016). Along a chain of "otherness" in American Jewish social spaces, recent immigrants may serve as reminders that American Jewry is to some extent being steadily reconstituted, and thus has not completed its processes of integration. The interplay between "otherness," distinctiveness, and integration partly reflects previous experiences and partly marks new challenges.

A node in which these different dimensions converge may be seen is the ongoing question of "Jews of Color." The overlapping of racial, ethnic, and national criteria and their socioeconomic, cultural, and religious connections raises fundamental questions as to the way the inclusion-exclusion dyad in community life is conceptually and practically approached (DellaPergola 2020b). The undifferentiated incorporation of Hispanic, Sephardic, Mizrachi, Asian, and Middle Eastern-if it occurshomogenizes an otherwise distinctive population, with its various trajectories and cultures. It may be read as a counterreaction to the racialized ethnicity for Hispanic/ Latino which largely excluded Latin American Jews. A twofold dilemmatic ascription of identity and identification emerges - that of Latinos, who are generally seen as non-white in the US, and that of Jews, who are viewed as white (Bokser Liwerant 2015c).

The initial questions of whether these immigrants should be classified primarily as Jewish, hence white, or whether their national identities as Argentine, Mexican, or Cuban weaken their Jewish ethno-religious identity must be weighed against the more complex issue of equating tout court Jews with whites, equivocally phrased as Ashkenazi hegemony or "whiteness." Should social scientists show some hesitation at applying categories taken from a racialized reality visà-vis universalizing narratives and ethnic divisions? How does the equation of Jews with whites fit into a social and political context that shows signs of white supremacy and antisemitism?

The subjective and socially expressed experiences of Latin American Jews are quite diverse. Boundary maintenance between origin groups may increase in complexity by interactions and by the plausibility of multiple identities and corresponding organizational structures. Various permutations take place, including reaffirmation, intermingling, and disentanglement, as variegated subgroups 
deploy in and around concurrent ethno-cultural-national (country of origin) boundaries in common spaces, intergenerational and communal (Brubaker 2006, 2015c).

Latin American Jewish migration to the US implies an altered stance vis-à-vis the connection to Israel; a geographically diverse transnationalism replaces older binary connections. That does not necessarily imply the weakening of attachments, but rather their re-signification. Israel was historically perceived by Latin American Jews as a vital space for those in need, in addition to its role as a sovereign political center and a focal axis of structural development. In the US, this amalgam may be readjusted as the "need" element makes way for other expressions of attachment and identification. Moreover, North American Jewish institutions become for their country of origin an important source of direct political support and a model for collective organization. This change must also be pondered considering the hypothesis of American Jewish self-distancing from Israel, which has elicited much debate (Cohen and Kelman 2009; DellaPergola 2010; Goldscheider 2010; Sasson et al. 2010). New data throw light both on meaningful attachment and on the age differentiation-an expression of prevailing changing dynamics (Pew Research Center 2021).

Latin American Jewish youth in the US increasingly participate in Birthright (Taglit), which has become an alternative to the study trips and intensive youth programs (hakhsharot) common in their countries of origin (Sasson et al. 2010). In this context, educational trips to Israel may be seen as fragments of the cultural and institutional practices for which Israel is conceived of as a site for the symbolic encoding of meanings and the formation of a sense of belonging while the awareness of an interconnected Jewish world is strengthened. Interactions between Israel and diaspora Jewish communities and their role in building Jewish identities exhibit complex dynamics_-plural meanings of center-home (spiritual, symbolic, material) and transnational ideational motives. In this regard, youth trips may be conceptualized as a praxis that reveals the unique convergence of modern nationalism with the growing practical and conceptual presence of transnationalism in the Jewish world, thus shedding light on the changing role of the center or homeland in guaranteeing the continuity of the diaspora (Kelner 2010; Bokser Liwerant 2016b). Thus, trips oscillate between links and bonds to the nation-state and diaspora-building as two interdependent pillars of the continuity of the collective. This interaction becomes challenging in the light of the rise of new identities with different levels of aggregation-both primordial and elective-and their renewed importance in the shaping of global, national, and local communal spheres.

\section{A Global Memory}

The multiplication, pluralization, and diversification of semantic-ideological and institutional connections between major arenas of Jewish life that develop between community and society-between the public and the private arenas-, as well as the components of collective identities, are defined by Eisenstadt (2010) as the crystallization of a new civilizational constellation. In this context, new relations between identity referents emerge. As such, the memory of the Shoah 
has progressively become an identification focus. It can be interpreted as located at the crossroads between collective memory-the memory of personal experiences or those of the group of belonging - and historical memory-which is mediated by its representations, symbols, and sites - as proposed by Halbwachs (1980). Besides its inherent and essential weight, it implies the culture of circulation, oscillating between Israel and the Shoah. Political developments within the Jewish state initially projected the Shoah as an identity referent, an iconic one, often above even the contents of the national state project. Israel gradually took on the role of collective memory keeper and shares it today with a reconfigured Jewish and non-Jewish world. Indeed, successive wars brought the recovery of its memory; the risk implied reinforced the conception of existential threat. Gradually, the increasing emergence of critical stands against Zionism and the Jewish state led to stripping the Jewish condition of its refugee profile and replacing it with a transfiguration that turned the victim into a victimizer, the refugee into the origin and cause of new exiles.

However, the transformation of the memory of the Shoah into a new identity paradigm was built inside the Jewish world not only as the road traced by the search of the past, but also as a counter-reference to the Jewish nation-state, as part of the claim for its universal over its particular meaning. The ideal of a cosmopolitan Judaism that seeks to construct a common human consciousness based on reducing ethnic or territorial barriers was constructed through the state-exile binomial. Its extreme conception questioned the Jewish national paradigm, seeing it as a threat that could "eradicate the certainty of uprooting, the mere entrenchment of the word, the legacy of the Prophets and the custodians of the books" (Steiner, 1985; Butler 2004). Exile and memory of destruction thus come together in a simultaneously tragic and heroic exiled figure. Head-on questioning of the State of Israel has emerged from this approach in the most pivotal moments of the Palestinian conflict. Yet, the paradoxical reversal of the centrality and meaning of the memory of the Shoah today finds expression in central arguments of representatives of post- and de-colonial thought, questioning and condemning it as part of the Western effort to displace and reject other genocides. Colonial racism is analyzed within the framework of the Holocaust and colonialism remembrance, and thus represents the Western, Eurocentric remembrance paradigm (Mignolo 2009; Grosfogel 2009).

The memory of the Shoah has also sought to explain its similarity to other genocides (Bokser Liwerant, Gleizer and Siman, 2016). In a world where globalization trends intensify antisemitic expressions, the idea of a universalizing memory sought to counter them. In Argentina, for instance, in light of the repression and antisemitic attacks starting in the late 1980s, the Shoah emerged as the axis of a new paradigm of memory and remembrance which sought to recover a thread of linkages between the traumatic episodes of Argentine reality and the Shoah. The latter connected with the repressive military dictatorship, the desaparecidos, the impunity and lack of justice. The 1994 bombing of the iconic building of AMIA - and two years earlier, the Israeli Embassy-were interpreted as one more link in the long chain of historical hate. They were also incorporated as part of a broad movement that fought for memory and justice, aiming to reconstruct the 
public sphere and redefine the place of a minority in the legitimate frame of full citizenship (Senkman 2005, 2008). Simultaneously, universalizing the memory of the Shoah also meant shifting emphasis from the mass destruction of a people to the understanding of individual suffering and its moral consequences, as shown by the perspective of the American ethos and the Jewish present of integration.

A full circle of changing patterns of cultural representations and social relations has a direct impact on associational dynamics and institutional formations that shape the structural underpinnings of Jewish life, enhanced by the digitalization of world communications, which has favored transnational ethnic and religious associations and virtual communities. The interpretation of belonging is less ideologically homogeneous while, paradoxically, the emergence of new nationalisms take place. These processes interact with the reconfiguration of communities that are exposed to social and cultural frameworks subject both to boundary erosion and to the organized spheres for boundary maintenance.

\section{Concluding Remarks}

The central trends and issues analyzed shed light on the Americas as a diverse territorial, geopolitical, economic, social, multiethnic, and cultural entity-ideally one, in reality diverse. The global Jewish world, for its part, was the carrier of its own diversity: its life parameters in the national and regional spaces were built on commonalities and inner differences that, as analyzed here, found expression on several spheres-from education and communal patterns of organization to the place of Jewish individuals and communities in the public sphere, as well as the role of and links with Israel.

Solid substrata of various forms of associational and institutional underpinnings provided the ground for common challenges and collective cohesion. Diasporabuilding emerged as the territory where the collective became shaped and reshaped. Differing interactions between primordial and elective identities-accelerated by globalization processes - varied between North and South and within each region and country. Changes over time and the pluralization and diversification of social life posed new challenges that led to the redefinition of the spaces where collective and individual possibilities develop.

Having analyzed the main conceptual and empirical lenses to account for the experience of Jews in the Americas, several questions emerge before us. We need to cross the national borders where Jewish diasporas dwell in an effort to understand the globality of the Jewish condition and also to understand the current dynamics of transnationalism. Are we going to see more convergence or divergence between the North and the South? Will globalization trends reach a maximum limit, followed by regression? Are the Jewish Americas moving toward a position of isolation or one of continued participation with world Jewry and Israel? Will the Americas and Israel build together a new poly-centered or de-centered matrix, or will fragmentation and antagonism overcome consensus-building? Will our broad field of knowledge-its theoretical, methodological formulations and our epistemic communities-be receptive to the changes required to face increased complexity and uncertainty? 
Regarding our first query, no easy assumption or one-dimensional approach seems adequate to produce a serious answer. We may broadly affirm that convergences and divergences display differentially within the economic, political, social, and cultural spheres. While the social sciences have studied the achievements of globalization processes - the growing interconnection between countries, economies and societies, collaboration in science, the circulation of cultures and human mobility itself - new expressions point to increased differentiation and inequalities between regions and countries, as well as within societies and communities. These processes are made evident by the growing paradox of the dynamics of integration-fragmentation, inclusion-exclusion, and dispersion-concentration (Cicchelli 2018).

Furthermore, globalization today is confronted by nationalist and isolationist trends. While not only the magnitude of the COVID-19 pandemic (and its resulting disruptions and imbalances) but also its possible solutions enhance the need for collaboration and global governance, peaks of nationalism are simultaneously looming. Both moments are seen as irreconcilable: the different governments tried to respond in the short term, each with its own profile and capabilities, while at the same time they lost legitimacy within their societies. The picture differed in the US, in Canada, and in the various Latin American societies. It may become enhanced by the fact that the differing scales of poverty and social inequality will probably deepen the gap between the regions, leading to the intensification of migration and bringing new migration crises and movement from the South to the North and from the North elsewhere.

While the Americas are more interdependent than in the past, we are witnessing different paths of restructuring regional and national processes. Democracies in the North and democratization in the South may further lead Jews and Jewish life to a shift from the focus on differences of a center-linked diaspora to a broader focus that encompasses emerging civic commonalities and transnational links as well. However, both this tendency and the renewal of collective affirmation draw challenging scenarios. The prevailing inner divisions are expressed in differing institutional capabilities by the various sectors. Indeed, the sectorialization of Jewish life has seriously challenged the existing forms of organization and of leadership and underlines the need for appropriate spaces where inner differences may be negotiated. 
We may think of a scenario of a world Jewish network-society articulated between diverse focal places of Jewish life. A Jewish world might coalesce in global and integral terms based on networks and relationships, links, and interactions that include voluntary and compulsory frameworks, primordial and elective foci of identities, associative and institutionalized structures. It would be a world in which plural identities would claim differentiated approaches to individuals and institutional orders as agents of changes.

However, we must question whether the inner divisions of Jewish life-religious, political, cultural, and socioeconomic - will lead to cross-national and overlapping sectorial relations blurring but not necessarily bringing the diaspora communities and Israel closer. The continental dynamics have been, although differentially, connected to Israel. Will American diaspora communities continue to maintain changing but strong links with Israel, or will the divergences lead to fragmentation?

And again, while the US, Canadian, and Latin American communities developed, as analyzed, differential bilateral functionalities, the importance attributed to the center-home duality by various sectors reflects the changing profile of an ethnonational diaspora entering new transnational dynamics. Future patterns of migration, geographical mobility, and its implications, the reshaping of existing and newly created communities, the expansion of material and symbolic boundaries, and their redefinition in a mobile context are all processes that will influence and modify the links with Israel. The interdependence between the nation-state-home (concrete, ideational, putative) and diaspora-building - strongly conditioned by varying Jewish models of collective life-develops along a diversified world of identities and religious and political allegiances.

The potential dynamics of interdependence, disjuncture, and convergences among these axes are closely related to the developments in Israel. While in the US the liberal sectors' increased criticism of Israel's occupation of the Palestinian territories and its lack of official recognition of all the Jewish religious streams have acted as dispute referents vis-à-vis Israel, the latter has maintained its centrality and unavoidability in the public conversation. How distancing and disaffiliation from the organized Jewish community will interact with the nexus with Israel is an open question. Will it be defined by political and cultural dissent?

Canadian Jewry has been homogeneously closer to Israel, and Latin American Jewish communities may well be able to continue to develop their relation at the crossroads of ideology and needs.

Our triad-globalization, transnationalism, and diaspora-highlights singular patterns defined by the stability and plasticity of the Jewish historical trajectory. However, regarding the epistemic challenges we posed, understanding the triad in the Americas demands that we work on the conceptual and methodological mediations and in-depth complementary relations between differing analytical levels and disciplines.

The former has been approached by Hartman's analytical model. Though focused on the individual and the family, it may be projected to wider comparative Jewish populations. It characterizes different levels of ecological factors influencing Jewish life cycles and populations at different times in history and in different geographical 
contexts-microsystem, mesosystem, macrosystem, chronosystem, and exosystem (Hartman 2020).

Approaching the challenge from the perspective of the disciplinary interaction, the question arises of which is the space where these articulations are to be formulated in order to favor encounters between various disciplinary logics, each with its own specialized language, methodological resources, topical focuses, and cognitive identity. How do we transition from community to society, from homeland to diaspora, from individual to group, from community to nation and state, from country to region, and from there to new centers of existence or interaction?

We do move from social territory to the de-territorialization of culture; from the everyday existence inside and out of institutions; from the de-privatization of religion to new circuits of circulation, personal forms of lending meaning and significance to belonging; from past to present; and, above all, from concrete particularity to concrete universality between disciplines (see Fig. 3). 


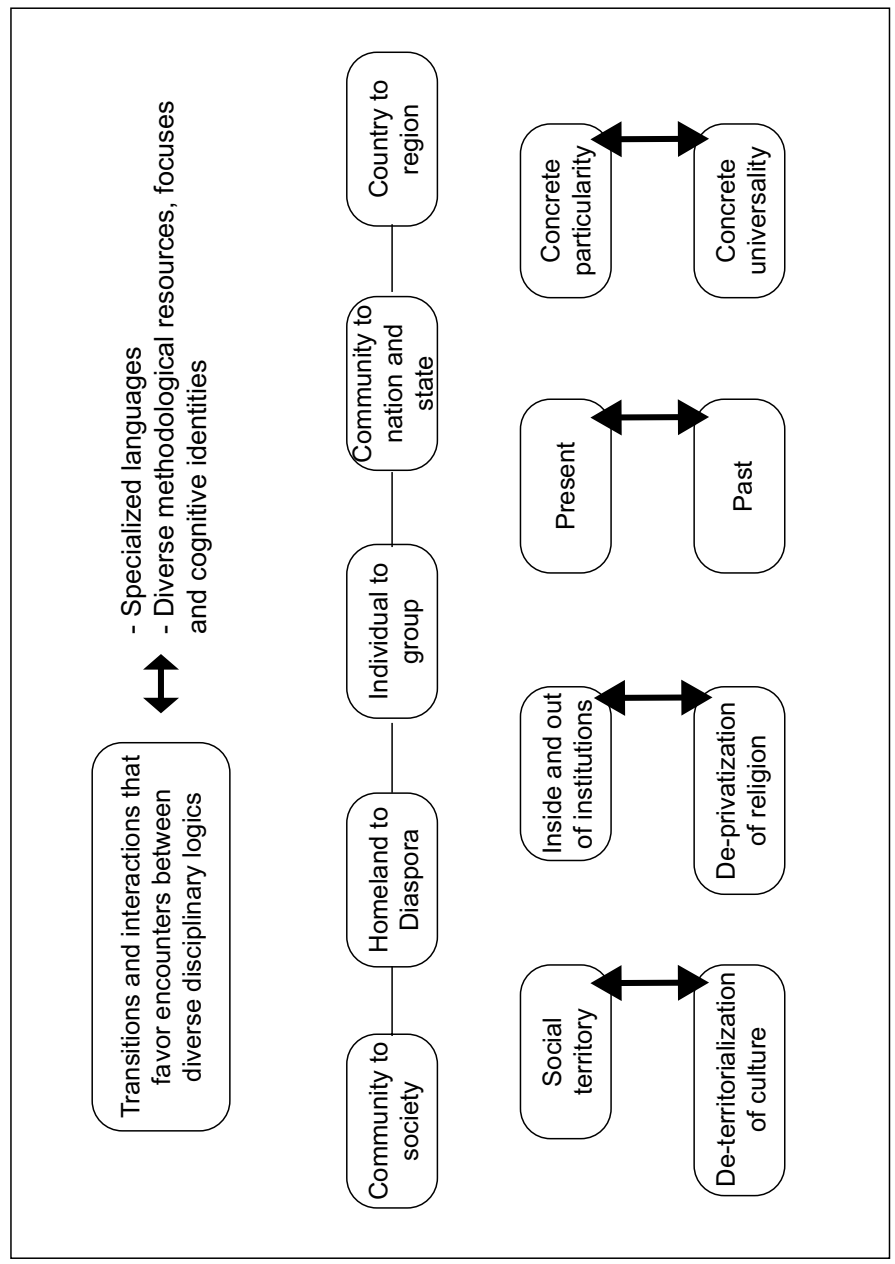

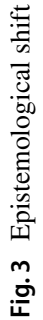


Further conceptual elaborations and research will stimulate the need to transition from the individual Jewish identity focus to the current challenges of continuity. The new individual turn needs to be theoretically connected to the interdisciplinarity of what social sciences call the subjective turn and its intersection with collective memory and values, not just individual but shared, public, and historical as well, and the concrete orders where memory and values are recreated and transmitted.

\section{References}

Abella, Isabella, and Harold Troper. 1982. None is too many: Canada and the Jews of Europe, 19331948. Toronto: Lester \& Orpen Dennys.

Abella, Irving. 2006. Presidential address: Jews, human rights and the making of a new Canada. Journal of the Canadian Historical Association 11 (1): 3-15.

Alexander, Jeffrey. 2006. The Civil sphere. New York: Oxford University Press.

Allen, Robert, Tommy Murphy, and Eric Schneider. 2012. The colonial origins of the divergence in the Americas: A labor market approach. The Journal of Economic History 72 (4): 863-894.

Alroey, Gur. 2008. Aliya to America? A Comparative Look at Jewish Mass Migration, 1881-1914. Modern Judaism 28 (2): 109-133.

Amelina, Anna, Devrimsel Nergiz, Thomas Faist, and Nina Glick Schiller (eds.). 2012. Beyond methodological nationalism: research methodologies for cross-border studies. Abingdon: Routledge

Anteby-Yemini, Lisa, and William Berthomière. 2005. Diaspora: A look back on a concept. Bulletin Du Centre De Recherche Français à Jérusalem 16: 262-270.

Appadurai, Arjun. 1996. Modernity at large. Cultural dimension of globalization. Minneapolis: University of Minnesota Press.

Aran, Gideon. 1991. Jewish fundamentalism: The block of the faithful in Israel (Gush Emunim). In Fundamentalism Observed, ed. Martin Marty and Scott Appleby. Chicago: University of Chicago Press.

Asscher, Omri, and Offer Shiff. 2019. Diasporic stances, homeland prisms: Representing diaspora in the homeland as internal negotiation of national identity. Diaspora Studies 13 (1): 1-15.

Avni, Haim., Judit Bokser Liwerant, Margalit Bejarano, Sergio DellaPergola. (eds.). 2011. Pertenencia y alteridad. Judíos en/de América Latina: Cuarenta años de cambios. Madrid/Frankfurt/Mexico City: Iberoamericana/Vervuert/Bonilla Artigas Editores.

Avni, Haim. 1976. El sionismo y su arraigo en América Latina. Jerusalem: The Hebrew University.

Bannerji, Himani. 2020. The ideological condition Selected essays on history, race and gender. Boston/ Leiden: Brill.

Bauböck, Rainer, and Thomas Faist. 2010. Diaspora and transnationalism concepts, theories and methods. Amsterdam: Amsterdam University Press.

Beck, Ulrich. 2007. La condition cosmopolite et le piège du nationalisme méthodologique. In Les sciences sociales en mutation, ed. M. Wieviorka, 223-236. Auxerre: Éditions Sciences Humaines.

Bellah, Robert. 1967. Civil Religion in America. Daedalus: Journal of the American Academy of Arts and Sciences 96 (1): 1-21.

Ben-Rafael, Eliezer, Yitzhak Sternberg, Judit Bokser Liwerant, \& Yosef Gorni. (eds.). 2009. Transnationalism: Diasporas and the advent of a new (dis)order. Boston/Leiden: Brill.

Ben-Rafael, E. 2013. Diaspora. Current Sociology.

Ben-Rafael, Eliezer. 2013b. Las Diasporas Transnacionales: Una nueva era o un nuevo mito? Revista Mexicana de Ciencias Políticas y Sociales. México, UNAM, (LVIII 219):189-224.

Ben-Rafael, Eliezer, and Yitzhak Sternberg. 2016a. With and beyond Shmuel N Eisenstadt: Transglobality. In Varieties of Multiple Modernities: New research design, ed. Gerhard Preyer and Michael Sussman. Boston/Leiden: Brill.

Besser, Mordechai. 2020. A census of Jewish day schools in the United States 2018-2019. New York: Avi Chai.

Bokser Liwerant, Judit. 1991. El movimiento nacional judío. El sionismo en México, 1922-1947. Mexico: Faculty of Political and Social Sciences, UNAM. 
Bokser Liwerant, Judit. 2002. Globalization and collective identities. Social Compass 49: 253-271.

Bokser Liwerant, Judit. 2008b. Latin American Jewish Identities: Past and present challenges. The Mexican Case in a Comparative Perspective. ed. J. Bokser Liwerant, 81-105. Boston/Leiden: Brill.

Bokser Liwerant, Judit. 2009. Latin American Jews. A transnational diaspora. In Transnationalism: diasporas and the advent of a new (dis)order, eds. Eliezer Ben-Rafael, Yitzhak Sternberg, Judit Bokser Liwerant, 351-374. Boston/Leiden: Brill.

Bokser Liwerant, Judit, Sergio DellaPergola, and Leonardo Senkman (eds.). 2010. Latin American Jews in a transnational world. Redefining and relocating Jewish experience and identities on four continents [Research project report]. Jerusalem/Mexico City: The Hebrew University of Jerusalem/ UNAM

Bokser Liwerant, Judit 2013. Diásporas y transnacionalismo. Nuevas indagaciones sobre los judíos latinoamericanos hoy. In Judaica latinoamericana VII, 11-71. Jerusalem: Hebrew University of Jerusalem/AMILAT.

Bokser Liwerant, Judit. 2013a. Being national, being transnational: Snapshots of belonging and citizenship. In Shifting frontiers of citizenship: The Latin America experience, eds. Mario Sznajder, Luis Roniger, \& Carlos Forment, 343-365. Boston/Leiden: Brill.

Bokser Liwerant, Judit. 2013b. Latin American Jews in the United States: community and belonging in times of transnationalism. Contemporary Jewry 33(1-2): 121-143.

Bokser Liwerant, Judit. 2015. El educador judío latinoamericano en un mundo transnacional. México/ Jerusalem: Bonilla Artigas/Hebrew University of Jerusalem

Bokser Liwerant, Judit. 2015a. Globalization and transnationalism: facing new realities, narratives and conceptual challenges. In Penser global. Internationalization et globalization des sciences humaines et sociales, eds. Michel Wieviorka, Laurent Lévi-Strauss and Gwenaëlle Lieppe, 309336. Paris: Maison des Sciences de L'Homme.

Bokser Liwerant, Judit. 2015b. Thinking Multiple Modernities from Latin America's perspective: complexity, periphery and diversity. In Varieties of Multiple Modernities. New Research Design, eds. Michael Sussman and Gerhard Preyer, 177-205. Boston/Leiden: Brill.

Bokser Liwerant, Judit. 2015c. Transnational expansions of Latin American Jewish life in times of migration: A mosaic of experiences in the United States. In Research in Jewish demography and identity, eds. Eli Lederhendler, \& Uzi Rebhun, 198-240. Brighton: Academic Studies Press

Bokser Liwerant, Judit, Daniella Gleizer and Yael Siman. 2016a. Conceptual and methodological clues for approaching the connections between Mexico and the Holocaust: Separate or Interconnected Histories? Contemporary Review of the Middle East 3(3), 1-37, 2016, SAGE Publications

Bokser Liwerant, Judit. 2016b. Expanding frontiers and affirming belonging: Youth travel to Israel - A view from Latin America. Hagira -Israel Journal of Migration, 122-158.

Bokser Liwerant, Judit. 2016c. The changing status of Zionism and Israel in Latin American Jewry. In Handbook of Israel: The major debates, eds. Eliezer Ben Rafael, Julius Schoeps, Yitzhak Sternberg and Olag Glokner, 998-1027. Berlin: De Gruyter.

Bokser Liwerant, Judit. 2019. Acercamientos conceptuales y socio-históricos a Múltiples Modernidades: secularización, laicidad e identidades colectivas. In Escenarios actuales de la laicidad en América Latina, eds. Pauline Capdeville and Fernando Arletazzen, 31-65. Mexico: IIJ-UNAM.

Biale, David, Michael Galchinsky, and Susannah Heschel. 1998. Insider/outsider: American Jews and multiculturalism. Berkeley: University of California Press.

Bourdieu, Pierre. 1986. The forms of capital. In Handbook of theory and research for the sociology of education, ed. J.G. Richardson, 241-258. New York: Greenwood Press.

Brah, Avtar. 1996. Cartographies of diaspora: Contesting identities. London: Routledge.

Braudel, Fernand. 1986. Las civilizaciones actuales: Estudio de historia económica y social. Madrid: Tecnos.

Brenner, Frederic. 2003. Diaspora: Homelands in exile. London: Bloomsbury.

Brinkmann, Tobias. 2014. "German Jews?" Reassessing the history of nineteenth-century Jewish immigrants in the United States. In Transnational traditions, eds. Ava F. Kahn and Adam D. Mendelsohn, 144-164. Detroit: Wayne State University Press.

Brown, Michael. 2007. Canadian Jews and multiculturalism: Myths and realities. Jewish Political Studies Review 19 (3/4): 57-75.

Brubaker, Rogers. 1994. Diasporas. Cultural Anthropology 9 (3): 302-338.

Brubaker, Rogers. 2006. Ethnicity without groups. Cambridge: Harvard University Press.

Bruneau, Michel. 1995. Diasporas. Montpellier: GIP Reclus. 
Brym, Robert (ed.). 2018. The future of Canada's territorial borders and personal boundaries: proceedings of the third S.D. Clark symposium on the future of Canadian society. Oakville: Rock's Mills Press.

Brym, Robert, Keith Neuman, and Rhonda Lenton. 2018. 2018 survey of Jews in Canada. Toronto: Environics Institute for Survey Research.

Burla, Shahar. 2015. The Diaspora and the homeland: Political goals in the construction of Israeli narratives to the Diaspora. Israel Affairs 21: 602-619.

Butler, Judith. 2004. Jews and the bi-national State. Logos 3(1). http://www.logosjournal.com/butler.htm

Casanova, Jose. 1994. Public religions in the modern world. Chicago: University of Chicago Press.

Castles, Stephen. 2000. International migration at the beginning of the twenty-first century: Global trends and issues. International Social Science Journal 165: 269-281.

Cicchelli, Vincenzo. 2018. Plural and shared: The sociology of a cosmopolitan world. Boston/Leiden: Brill.

Clifford, James. 1994. Diasporas. Cultural Anthropology 9 (3): 302-338.

Cohen, Steven. 1988. American Assimilation or Jewish Revival? Bloomington: Indiana University Press.

Cohen, Naomi. 2003. The Americanization of Zionism, 1987-1948. Boston: Brandeis University Press.

Cohen, Robin. 2008. Global diasporas: An introduction. London/New York: Routledge.

Cohen, Steven, and Arnold M. Eisen. 2000. The Jew within: Self, family and community in America. Bloomington: Indiana University Press.

Cohen, Steven, and Ari Kelman. 2009. Beyond distancing: Young adult American Jews and their Alienation from Israel. New York: Andrea and Charles Bronfman Philanthropies.

Coleman, James. 1988. Social capital in the creation of human capital. American Journal of Sociology 94: S95-S120.

Coleman, William, and Geoffrey Underhill. 2012. Regionalism and global economic integration: Europe, Asia and the Americas. London: Routledge.

Crespo Gaggioti, Horacio Alberto, Gabriel A. Kozel, and Alexander Betancourt Mendieta. 2018. ¿Tienen las Américas una historia común? Herbert E. Bolton, las fronteras y la "Gran América”. Cuernavaca: Universidad Autónoma del Estado de Morelos.

Danzger, Herbert. 1989. Returning to tradition: The contemporary revival of orthodox Judaism. New Haven/London: Yale University Press.

Davie, Grace. 2007. Vicarious religion: A methodological challenge. In Everyday religion: Observing modern religious lives, ed. N. Ammerman, 21-36. Oxford: Oxford University Press.

De Tocqueville, Alexis. 2002. Democracy in America. Chicago: University of Chicago Press. (Original work published 1835).

DellaPergola, Sergio. 2010. Distancing, yet one. Contemporary Jewry 30 (2-3): 183-190.

DellaPergola, Sergio. 2020c. World Jewish population, 2019 American Jewish Year Book. Berlin: Springer.

DellaPergola, S. 2008. Jewish autonomy and dependency: Latin America in global perspective. In Identities in an era of globalization and multiculturalism, ed. E. Ben-Rafael, J. Bokser Liwerant, Y. Gorny and R. Rein. Boston/Leiden: Brill.

DellaPergola, S. 2011. ¿Cuántos somos hoy? Investigación y narrativa sobre población judía en América Latina. In Pertenencia y alteridad. Judíos en/de América Latina: cuarenta años de cambios, eds. A. Haim, J. Bokser Liwerant, S. DellaPergola, M. Bejarano and L. Senkman, 305-340. Madrid/ Frankfurt/Mexico City: Iberoamericana/Vervuert/Bonilla Artigas Editores.

DellaPergola, Sergio. 2020a. Diaspora vs. Homeland: Development, unemployment and ethnic migration to Israel. 1991-2019. Jerusalem: Hebrew University of Jerusalem.

DellaPergola, Sergio. 2020b. Jews of Color. A Memo. Association for Social Scientific Study of Jewry.

Dieckhoff, Alain. 2003. Israël: Une nation en armes entre dynamiques individualistes et permanence du nationalisme. In Guerres et sociétés États et violence après la Guerre froide, eds. Pierre Hassner and Roland Marchal, 229-256. Paris: Éditions Karthala.

Diner, Hasia. 2004. The Jews of the United States, 1654 to 2000. Berkeley: University of California Press.

Domínguez Ortiz, Antonio. 1976. Sociedad y Estado en el siglo XVIII español. México: Ariel.

Don-Yehiya, Eliezer. 2014. Messianism and politics: The ideological transformation of religious Zionism. Israel Studies 19 (2): 239-263.

Eisen, Arnold. 1986. Galut: Modern Jewish reflection on homelessness and homecoming. Bloomington: Indiana University Press. 
Eisen, Arnold. 2014. Zionism, American Jewry, and the 'Negation of Diaspora.' In Between Jewish tradition and Modernity: Rethinking an Old Opposition, Essays in Honor of David Ellenson, ed. Michael A. Meyer and David N. Myers, 175-191. Detroit: Wayne State University Press.

Eisenstadt, Shmuel Noah. 2000. Multiple modernities. Daedalus 129 (1): 1-29.

Eisenstadt, Shmuel Noah. 2002. The first multiple modernities: Collective identity, public spheres and political order in the Americas. In Globality and multiple modernities, eds. Luis Roniger and Carlos Waisman, 7-28. Brighton: Sussex Academic Press.

Eisenstadt, Shmuel Noah. 2010. The new religious constellations in the frameworks of contemporary globalization and civilizational transformation. In World religions and multiculturalism: A dialectical relation, eds. Eliezer Ben Rafael and Yitzhak Shterenberg, World Religions and multiculturalism, 21-41. Boston/Leiden: Brill.

Elazar, Daniel, and Stuart Cohen. 1985. The Jewish Polity: Jewish political organizations from Biblical times to the present. Bloomington: Indiana University Press.

Esman, Milton. 2009. Diasporas in the contemporary world. Cambridge: Polity.

Fischer, Shlomo. 2010. Judaism and global religious trends: Some contemporary developments. In World religions and multiculturalism A dialectical relation, eds. Eliezer Ben-Rafael and Yitzhak Sternberg, 263-294. Boston/Leiden: Brill.

Fischer, Shlomo, and Suzanne Last Stone. 2012. Jewish identity and identification: new patterns, meanings and networks. Jerusalem: Jewish People Policy Institute.

Friedman, Joshua, and Moshe Kornfeld. 2018. Identity projects: Philanthropy, neoliberalism, and Jewish cultural production. American Jewish History 102 (4): 537-561.

Gaggioti C., Horacio Alberto, Gabriel Andrés Kozel, and Alexander Betancourt Mendieta. 2018. ¿Tienen las Américas una historia común? Herbert E. Bolton, las fronteras y la "Gran América". Cuernavaca: Universidad Autónoma del Estado de Morelos.

Giddens, Anthony, Ulrich Beck, and Scott Lash. 1994. Reflexive modernization Politics, tradition and aesthetics in the modern social order. Cambridge: Polity.

Giddens, Anthony. 2002. Runaway world: How globalization is reshaping our lives. London: Profile Books.

Glick Schiller, Nina, Linda Basch, and Cristina Blanc-Szanton. 1995. From immigrant to transmigrant: theorizing transnational migration. Anthropological quarterly 68(1): 48-63.

Goldscheider, Calvin and Alan Zuckerman. 1984. The transformation of the Jews. Chicago: University of Chicago Press.

Goldscheider, Calvin. 2003. Are American Jews vanishing again? Contexts 2 (1): 18-24.

Goldscheider, Calvin. 2010. American and Israeli Jews: Oneness and distancing. Contemporary Jewry 30 (2): 205-211.

Greenstein, Michael. 1989. Third solitudes: Tradition and discontinuity in Jewish-Canadian literature. Montreal: McGill-Queen's University Press.

Grosfogel, Ramon. 2009. Human rights and anti-semitism after Gaza. Universitas Humanística 68: 157-177.

Guo, Shibao, and Lloyd Wong. 2015. Revisiting multiculturalism in Canada: Theories, policies and debates. Berlin: Springer.

Halbwachs, Maurice. 1980. The collective memory. New York: Harper and Row.

Hartman, Harriet. 2020. The 2019 Sklare Address: How gender and family still matter for contemporary Jewry. Contemporary Jewry 40: 161-185.

Held, David, Anthony McGrew, David Goldblatt, and Jonathan Perraton. 1999. Global transformations Politics, economics, culture. Stanford: Stanford University Press.

Herberg, Will. 1983. Protestant-Catholic-Jew: An essay in American religious sociology. Chicago: University of Chicago Press.

Hollinger, David. 1998. Jewish Identity, assimilation, and multiculturalism. In Creating American Jews, ed. Karen Mittelman, 52-59. Philadelphia: National Museum of American Jewish History.

Kahn, Ava F., and Adam D. Mendelsohn, eds. 2014. Transnational traditions. Detroit: Wayne State University Press.

Katz, Steven. 2010. Why is America different? American Jewry on its 350th anniversary. Lanham: University Press of America.

Kellerman, Aharon. 2006. Personal mobilities. New York: Routledge.

Kellerman, Aharon. 2020. Globalization and spatial mobilities: Commodities and people, capital, information and technology. Cheltenham: Edward Elgar Publishing. 
Kelner, Shaul. 2010. Tours that bind Diaspora, pilgrimage and Israeli birthright tourism. New York: New York University Press.

Kelner, Shaul. 2013. Religious ambivalence in Jewish American philanthropy. In Family, friend, foe? The relationship of religion and philanthropy in religious philanthropic organizations, ed. T.J. Davis, 28-49. Bloomington: Indiana University Press.

Khagram, Sanjeev, and Peggy Levitt. 2008. The transnational studies reader. Intersections and innovations. Abingdon: Routledge.

Kobrin, Rebecca. (ed.). 2012. Chosen capital: The Jewish encounter with American capitalism. New Brunswick: Rutgers University Press.

Kurtzer, Yehuda and Claire E. Sufrin. 2020. The new Jewish canon. Brighton: Academic Studies Press.

Lederhendler, Eli (ed.). 2000. The Six-Day War and world Jewry. Bethesda: University Press of Maryland.

Lederhendler, Eli. 2011. Studies in contemporary Jewry: Ethnicity and beyond: Theories and dilemmas of Jewish group demarcation. Oxford: Oxford University Press.

Lederhendler, Eli. 2019. Israel and America in Jewish American writing. In The New Jewish American literary studies, ed. V. Aarons, 59-73. Cambridge: Cambridge University Press.

Levinson, Julian Arnold. 2009. People of the (Secular) book: literary Anthologies and the making of Jewish identity in Postwar America. In Religion or ethnicity? Jewish Identities in evolution, ed. Zvi Gitelman, 132-150. New Brunswick: Rutgers University Press.

Levitt, Peggy. 2001. Transnational migration: Taking stock and future directions. Global Networks 1 (3): $195-216$.

Levitt, Peggy, and Nina Glick Schiller. 2004. Conceptualizing simultaneity: A transnational social perspective on society. International Migration Review XXXVII I (145): 595-629.

Limonic, Laura. 2019. Kugel and frijoles. Latino Jews in the United States. Detroit: Wayne State University Press.

Magid, Shaul. 2013. American post-Judaism: Identity and Renewal in a Postethnic Society. Bloomington: Indiana University Press.

Mays, Devi. 2020. Forging ties, forging passports: Migration and the modern Sephardi diaspora. Stanford: Stanford University Press.

Michels, Tony. 2010. Is America "different?" A critique of American Jewish exceptionalism. American Jewish History 96 (3): 201-224.

Mignolo, Walter. 2009. Dispensable and bare lives Coloniality and the hidden political/economic agenda of Modernity. Human Architecture: Journal of the Sociology of Self-Knowledge. VII (2): 69-88.

Miller, Helena, Lisa D. Grant, and Adam Pomson. 2011. International handbook of Jewish education. Berlin: Springer.

Moore, Deborah Dash. 2009. GI Jews: How World War II changed a generation. Cambridge: Harvard University Press.

Moya, Jose. 2011. Estudios sobre la diáspora: ¿Nuevos conceptos, enfoques y realidades? In Diásporas. In Reflexiones teóricas, ed. N. Golubov, 205-225. Mexico: CISAN-UNAM.

Nonini, Donald. 2002. Transnational migrants, globalization processes, and regimes of power and knowledge. Critical Asian Studies 34 (1): 3-17.

O’Haire, Daniel. 2008. Diaspora. Charleston: BookSurge Publishing.

Penkower, Monty Noam. 1985. American Jewry and the Holocaust: from Biltmore to the American Jewish Conference. Jewish Social Studies 47 (2): 95-114.

Pew Research Center. 2019. Latin America, Caribbean no longer world's fastest growing source of international migrants. https://www.pewresearch.org/fact-tank/2019/01/25/latin-america-caribbean-nolonger-worlds-fastest-growing-source-of-international-migrants/. Accessed June 152020.

Pew Research Center. 2021. Jewish Americans in 2020. Washington, D.C.: Pew Research Center.

Phillips, Bruce. 2005. American Judaism in the twenty-first century. In The Cambridge companion to American Judaism, ed. Dana Eva Kaplan, 397-416. Cambridge: Cambridge University Press.

Pomson, Alex, and Howard Deitcher. 2009. Jewish day schools, Jewish communities: A reconsideration. Liverpool: Liverpool University Press.

Portes, Alejandro, Luis Guarnizo, and Patricia Landolt. 1999. The study of transnationalism: Pitfalls and promise of an emergent research field. Ethnic and Racial Studies 22 (2): 217-237.

Preyer, Gerhard. 2013. The perspective of multiple modernities on S. N. Eisenstadt's sociology. Science and Society: Journal of Political and Moral Theory 30: 187-225. 
Pries, Ludger. 2008. Transnational societal spaces: Which units of analysis, reference and measurement. In Rethinking transnationalism: The meso-link of organization, ed. L. Pries, 1-20. Hoboken: Taylor \& Francis.

Quijano, Anibal. 1989. Paradoxes of Modernity in Latin America. International Journal of Politics, Culture, and Society 3 (2): 147-177.

Restad, Hilde. 2014. American exceptionalism: An idea that made a nation and remade the world. Abingdon: Routledge.

Robertson, Roland. 1992. Globalization: Social theory and global culture. New York: SAGE.

Rohrbacher, Angelika. 2016. Invisible fences: The construction of "insiders" and "outsiders" in Jewish historiography. Method \& Theory of the Study of Religion 28 (4/5): 337-364.

Roniger, Luis, and Carlos Waisman, eds. 2002. Globality and Multiple Modernities: Comparative North American and Latin American perspectives. Brighton: Sussex Academic Press.

Roniger, Luis. 2011. Transnational politics in Central America. Gainesville: University of Florida Press.

Safran, William. 1991. Diasporas in modern societies: Myths of homeland and return. Diaspora: A Journal of Transnational Studies 1 (1): 83-99.

Sagi, Avi, and Dov Schwartz. 2018. Religious Zionism and the Six day war: From realism to messianism. Abingdon: Routledge.

Sarna, Jonathan, ed. 1997. The American Jewish experience. New York: Holmes \& Meier.

Sarna, Jonathan. 2004. American Judaism: A history. New Haven: Yale University Press.

Sassen, Saskia. 1998. Globalization and its discontents: Essays on the new mobility of people and money. New York: The New Press.

Sasson, Theodore, Charles Kadushin, and Leonard Saxe. 2010. Trends in American Jewish attachment to Israel: An assessment of the "distancing" hypothesis. Contemporary Jewry 30 (2-3): 297-319.

Sasson, Theodore. 2015. The New American Zionism. New York: NYU Press.

Schiller, G., L.B. Nina, and C. Blanc-Szanton. 1995. From immigrant to transmigrant: Theorizing transnational migration. Anthropological Quarterly 68 (1): 48-63.

Scholte, Jan Aart. 1998. The globalization or world politics. In The globalization of world politics An introduction to International Relations, eds. John Baylis, Steve Smith, and Patricia Owens, 13-32. Oxford: Oxford University Press.

Senkman, L. 2005. Citizenship and Jewish identity: an experiment of the Argentinean Jewish community. Paper presented at Dinur Canter for Research in Jewish History, Jerusalem.

Senkman, L 2008. Klal Yisrael at the frontiers: the transnational Jewish experience in Argentina. In Identities in an era of globalization and multiculturalism. Latin America in the Jewish world, eds. Bokser Liwerant, J., E. Ben-Rafael, Y. Gorni and R. Rein, 125-150. Boston/Leiden: Brill.

Sheffer, G. 1986. A new field of study: modern diasporas in international politics. In Modern diasporas in international politics, ed. Gabriel Sheffer, 1-15. London: Croom Helm.

Shuval, Judith. 2002. Diaspora migration: Definitional ambiguities and a theoretical paradigm. Migration Pages 38 (5): 41-56.

Shuval, Judith. 2003. The dynamics of diaspora: theoretical implications of ambiguous concepts. In Diasporas and ethnic migrants: Germany, Israel and Russia in comparative perspective, ed. R. Münz and R. Ohliger. London: Frank Cass.

Silberman, Charles. 1985. A certain people: American Jews and their lives today. New York: Simon \& Schuster.

Steiner, George. 1985. Our homeland, the text. Salmagundi 66: 4-25.

Tartakover, Arie. 1958. Israeli Society. Ramat Gan: Massada.

Tickton Schuster, Diane. 2019. Portraits of Jewish learning: Viewing contemporary Jewish education close-in. Eugene: Wipf and Stock Publishers.

Troper, Harold, and Morton Weinfeld. 1988. Old wounds. New York: Viking/Penguin.

United Nations Development Programme. 2009. Human Development Report 2009. Overcoming barriers: Human mobility and development. New York: United Nations.

United Nations - Department of Economic and Social Affairs. 2019. International Migrant Stock 2019. https://www.un.org/en/development/desa/population/migration/data/estimates2/estimates19.asp. Accessed October 232020.

United Nations - Human Development Programme. 2009. Human Development Report 2009. Overcoming barriers: Human mobility and development. New York: United Nations.

United Nations Development Programme. 2020. Human Development Report 2009. Overcoming barriers: Human development and the Anthropocene. New York: United Nations. 
Urry, John. 2000. Sociology beyond societies. Mobilities for the twenty-first century. Abingdon: Routledge.

Van Hear, Nicholas. 1998. New Diasporas: The Mass Exodus, Dispersal and Regrouping of Migrant Communities. London: Taylor and Francis Group.

Voyé, Liliane. 2000. Secularization in a context of advanced modernity. In The secularization debate, eds. William. Swatos and Daniel V.A. Olson, 67-75. Lanham: Rowman \& Littlefield.

Wallerstein, Immanuel. 1974. The modern world-system capitalist agriculture and the origins of the European world-economy in the sixteenth century, vol. I. New York: Academic Press.

Wallerstein, Immanuel. 2011. The modern world-system III: Mercantilism and the consolidation of the European world-economy, 1600-1750. Berkeley: University of California Press.

Waters, Malcolm. 1995. Globalization. Abingdon: Routledge.

Waxman, Chaim. 1983. American Jews in transition. Philadelphia: Temple University Press.

Weinfeld, Morton. 2018. Like everyone else but different: The paradoxical success of Canadian Jews. Montreal: McGill-Queen's University Press.

Woocher, Jonathan. 1986. Sacred survival. The civil religion of American Jews. Bloomington: Indiana University Press.

Woocher, Jonathan. 2005. "Sacred survival" revisited: American Jewish civil religion in the new millennium. In The Cambridge companion to American Judaism, ed. Dana Eva Kaplan, 283-297. Cambridge: Cambridge University Press

Wooldridge, Adrian, and John Micklethwait. 2005. The right nation: Why America is different. New York: Penguin.

Yudice, George. 2006. ¿Una o varias identidades? Cultura, globalización y migraciones. Nueva Sociedad 201: 106-116.

Publisher's Note Springer Nature remains neutral with regard to jurisdictional claims in published maps and institutional affiliations.

Judit Bokser Liwerant holds a PhD Cum Laude in Social Sciences (Political Science). She is a Senior Full Time Professor of Political Science at the Universidad Nacional Autónoma de Mexico (UNAM); member of the Mexican Academy of Science and of the National Research System, and Distinguished Visiting Professor, the Hebrew University of Jerusalem, since 2013. She is the Director and Chief Editor of the Revista Mexicana de Ciencias Politicas y Sociales, and Co-editor of the series Jewish Identities in a Changing World (Brill). She has been the recipient of several national and international awards, including the Marshall Sklare Award. She is the author and editor of 14 books, over 100 book chapters, and over 90 scientific articles. In her research, political science, sociology, history, and contemporary Jewry converge. Among her research axes are Latin American Jewry; Modernity in its concurrent dynamics of homogeneity-diversity; Latin American Multiple Modernities; collective identities in the public sphere; globalization, diaspora and transnationalism. Selected publications: Belonging and Otherness. Jews in/ of Latin America (2011); Reconsidering Israel-Diaspora Relations (2014); Israel-Diaspora Relations: Continuities and Discontinuities (2021); Antisemitism (and related expressions of prejudice) in a global world. A view from Latin America (2021). 